Zeszyty Prawnicze $17.1 / 2017$

\title{
RECENZJE
}

\section{O SYMULOWANEJ NAUCE, CZYLI O NIEKOMPETENTNEJ, NIEUDOLNEJ I NIEUDANEJ REKONCEPTUALIZACJI SPOŁECZNEJ, KULTUROWEJ, GOSPODARCZEJ I POLITYCZNEJ HISTORII I RZECZYPOSPOLITEJ, NIERZETELNYM POSTĘPOWANIU HABILITACYJNYM I GROŹNYM POMRUKU METODOLOGICZNYM À LA OTWOCK}

\author{
naszym celem jest po prostu potępienie \\ intelektualnej hochsztaplerki i nieuczciwości
}

A. Sokal, J. Bricmont, s. 29

\section{Arogancja}

Wydana w 2011 r. rozprawa habilitacyjna Jana Sowy, Fantomowe ciało króla. Peryferyjne zmagania $z$ nowoczesna forma $a^{1}$, mogła wzbudzić zainteresowanie środowiska historycznego w Polsce, skoro jej Autor

\footnotetext{
1 Towarzystwo Autorów i Wydawców Prac Naukowych UNIVERSITAS, Kraków. Wydawnictwo nie poddało niestety Fantomowego ciała profesjonalnej recenzji wydawniczej, zaś recenzje opracowane w toku nowej procedury habilitacyjnej, po dwukrotnej zmianie recenzentów (!), przygotowane zostały w sposób drastycznie nierzetelny. Rozprawa stała się podstawą wszczęcia przez Centralną Komisję postępowania habilitacyjnego, skierowania go 28 maja 2012 r. przed Radę Wydziału Nauk Humanistycznych i Społecznych Szkoły Wyższej Psychologii Społecznej w Warszawie i nadania Janowi Sowie 28 maja 2013 r., tym razem - ku zdziwieniu obserwatora - przez
} 
zapowiadał dokonanie uzupełnienia luki, jaka w polskiej myśli społecznej stanowi brak systematycznej i kompleksowej reinterpretacji polskiej historii społecznej, kulturowej, gospodarczej i politycznej - czy też, mówiąc ogólnie, polskiego habitusu - przy wykorzystaniu takich narzędzi teoretycznych jak studia postkolonialne, teorie zależności, teologia polityczna, psychoanaliza oraz teoria hegemonii. To więc próba przepisania faktów i narracji, które sa powszechnie znane, interpretowane jednak - w mojej opinii - w niekompletny, a czasem błędny sposób [s. 34], wskazując, że zajmie się rekonceptualizacja politycznej historii I Rzeczypospolitej [s. 45]. Podkreślał, że nie poszukuje nowych danych: W niniejszej książce będzie to próba wyjaśnienia szczególnego habitusu i cywilizacyjnego zacofania Europy Środkowo-Wschodniej, w tym szczególnie Polski. Stosując historyczna perspektywę opisu i wyjaśniania, przyjmuje jednocześnie perspektywę interpretatora, a nie odkrywcy. Nie chodzi mi więc o poszukiwanie nowych danych, które zrewiduja obraz jakiejś epoki historycznej, ale o rekonfiguracje i reinterpretacje faktów, procesów i zjawisk juz opisanych w historiografii [s. 50], czy w innym miejscu: psychoanaliza Polski szlacheckiej nie będzie polegać na poszukiwaniu nieznanych sensacyjnych faktów, ale na poznawczej rekonfiguracji tego, co już doskonale wiemy. Chociaż nie wiemy, że to wiemy [s. 390]. Zadanie to ambitne, wymagające ogromnej wiedzy, które winno - jeśli zostanie poprawnie zrealizowane - otworzyć nowe perspektywy przed badaczami polskiej przeszłości. Tym bardziej, że Sowa nie chce ograniczać się do narzędzi (konceptualnych i metodologicznych) tylko jednej dyscypliny [s. 29], deklarując, że nie będzie unikać „wycieczek” na „cudze” terytoria: ekonomii, historii, psychologii, filozofii czy teorii kultury [s. 30]. Wszystko to łączy z pogłębionymi studiami nad historia, kultura i habitusem Europy Środkowo-Wschodniej, które przedstawiam w niniejszej książce [s. 30-31].

Ta rewizja dwustuletniego dorobku polskiej historiografii wzbudziła zainteresowanie - choć przede wszystkim niehistoryków² ${ }^{2}$ a liczne wy-

Radę Wydziału Kulturoznawstwa i Filologii SWPS, stopnia doktora habilitowanego nauk humanistycznych w dyscyplinie kulturoznawstwo.

2 W środowisku historyków zdecydowanie krytycznie wystąpiła Izabela Lewandowska-Malec: uznaje dzieło za „brak”, wykazując niekompetencję autora, I. LEwandowska-Malec, Artykuł recenzyjny książki Jana Sowy Fantomowe ciało króla. 
powiedzi na jej temat są w większości pełne aprobaty dla przeprowadzonych rozważań i uzyskanych wyników ${ }^{3}$. Pojawiają się przy tym daleko idące, nieodpowiedzialne, wręcz uzurpatorskie głosy, że książka Jana Sowy jest kolejna w ostatnich latach na rynku pozycja, która powinna skłonić historyków polskich do poważnego przemyślenia polityki, retoryki i dyskursów, jakimi posługują się w uprawianiu swojej dziedziny ${ }^{4}$. I sam Jan Sowa ma zastrzeżenia do sposobu prowadzenia badań naukowych przez środowisko historyków polskich: Jest to jedyna [eksponuje Sowa] dyscyplina humanistyczna w Polsce, która poza pojedynczymi badaczami i badaczkami w ogóle nie otwarła się na zmianę paradygmatu badań humanistycznych. Sowa nie akceptuje też polityki kadrowej w środowisku historyków pisząc: gdybym to ja miał decydować o awansach, stopniach i tytułach w środowisku historyków, wyglądałyby one inaczej niż teraz ${ }^{5}$. W naszym odczuciu zaczyna tu groźnie pobrzmiewać nuta z repertuaru metodologicznej konferencji otwockiej: Jest czymś niewiarygodnym, że posiadając w Polsce tak mocna instytucjonalnie historiografię i tak wielu

Peryferyjne zmagania z nowoczesna formą, "Krakowskie Studia z Historii Państwa i Prawa» 6(3)/2013, s. 285-301.

3 „Fantomowe ciało króla” to moim zdaniem jedna z najważniejszych książek jakie ukazały sie ostatnio w Polsce. Lektura obowiązkowa dla wszystkich, którzy o Polsce (i polityce polskiej) myśla poważnie - bez znaczenia z której strony politycznej barykady się znajdują. - pisał w 2012 r. na swoim blogu K. Nawratek. Głos zabierali m. in.: P. Bohuszewicz, Hermeneutyki sarmatyzmu, [w:] Tradycje szlacheckie we współczesnej kulturze polskiej. Przyblizenia i perspektywy badawcze, red. M. Lutomierski, Toruń 2014, s. 105-130; E. Flieger, Peryferyjne zmagania z forma Jana Sowy, «Sensus Historiae» 11.2/2013, s. 208-215; T. Gabiś, Dwaj Panowie S. o pożytkach z kolonizacji Polski, http://nowadebata.pl/2014/01/18/dwaj-panowie-s-o-pozytkach-z-kolonizacji-polski/, dostęp 23 listopada 2016 r.; Ł. ŁACHECKI, Rzeczypospolita lacanowska (wrzesień 2012), http://literatki.com/7512/jan-sowa-fantomowe-cialo-krola-rzeczpospolita-lacanowska, dostęp 23 listopada 2016 r.; B. Sienkiewicz, Państwo na niby, «Przegląd Polityczny» nr 115/116; A.T. STANisŁaWsKi, Niedojrzałość, bóle fantomowe i pustka, którq nazwano „złotym wiekiem”, «Ruch Literacki» 54.3 (318)//2013, K. ZAJAs, Fantazmaty Sarmaty albo historia Polskiej Kompanii Kresowej. O dzielnej książe Jana Sowy „Fantomowe ciało króla”, Teksty Drugie, «IBL PAN» 3/2012, s. 63-70; T. ZARYCKI http://www.iss. uw.edu.pl/zarycki/pdf/RecenzjaSowa.pdf, dostęp 23 listopada 2016 r.

\footnotetext{
4 K. Zajas, op. cit., s. 70.

5 J. SowA, Nota na temat artykułu J. Matuszewskiego, «SDPiPP», 18/2015.
} 
wcale nie najgorzej opłacanych historyków, tak słabo rozumiemy nasza zbiorowa przeszłość. [...] Winny jest również sam sposób uprawiania historiografii $w$ Polsce. Nie jest ona u nas nauka teoretyczno-pojęciowa. Historykom wiedza pomyliła się z informacjami i wydaje im się, że wystarczy transdukcyjna ${ }^{6}$ enumeracja faktów, aby już wiedzieć, co się stało. [...] Aby tę sytuacje poprawić, należałoby polskim historykom na jakiś czas zakazać badania jakichkolwiek nowych archiwów $i$ wywlekania na światło dzienne nieznanych faktów - zrozumienie i wyjaśnienie tego, co jest już znane, i tak kompletnie ich przerasta ${ }^{7}$, odkrywa pracownik Jagiellońskiej Akademii. W ocenie recenzentów procedury prowadzącej do naukowego awansu ksiązka habilitacyjna Jana Sowy jest rewelatorska, rewoltujaca i rewelacyjna, gdyż stanowi jakościowy skok $w$ badaniach nad Polska szlachecka [...] jest spójna, odkrywcza i inspirujaca metodologicznie - stwierdza Przemysław Czapliński, jej zaleta jest rozległa

6 ,Transdukcja' to przeniesienie lub przetworzenie - różnica ogromna. Por. np. równie dwuznaczne użycie w habilitacji terminu primordialny [s. 443, 528]: czytelnik nie wie, czy w grę wchodzi pierwszorzędna, podstawowa cecha, czy też pierwotna, najdawniejsza. Równie niejednoznaczny termin pikowanie (pikowanie samolotu, pikowanie roślin, pikowanie jako technika zdobienia mebli tapicerowanych, czy pikowanie jako technika wykorzystywana do ograniczania przemieszczania się materiałów wyścielających), dopiero po kilkukrotnym użyciu [s. 373, 374, 375, 378], niejednoznacznie wyjaśniono w sensie tapicerskim (s. 398). Habilitant udaje też często, że przeprowadza terminologiczne dystynkcje. Pojęciem „habitus” zdecydowałem się zastąpić tam, gdzie jest to możliwe, wątpliwą pod wieloma względami kategorię „tożsamości" (s. 13 przyp. 6). Następnie do tej wątpliwej kategorii odwoła się 70 razy, gdy doskonale omówiony w licznych opracowaniach habitus przywołany zostanie niespełna 30 razy. Przykładów takiej manipulacji terminologicznej mnóstwo. Por o ukrywaniu się pseudonaukowców za niejednoznacznością terminologicznej nowomowy, M. GARDNER, Pseudonauka i pseudouczeni, Warszawa 1966, s. 171 (polska edycja ocenzurowana). Tytuł oryginału: Fads and fallacies. In the name of science [I wyd. 1952]: He often has a tendency to write in a complex jargon, in many cases making use of terms and phrases he himself has coined. (ma często skłonność do zawiłego żargonu, używając raz po raz zwrotów przez siebie wymyślonych).

7 J. SowA, Kiedy dwa minusy nie powinny dawać plusa, Praktyka teoretyczna, http://www.praktykateoretyczna.pl/jan-sowa-kiedy-dwa-minusy-nie-powinny-dawac-plusa/2 dostęp 24 listopada 2016 r. Zwraca uwagę symptomatyczny, pretensjonalny, a niekompetentny tytuł: zawsze, gdy do minusa dodamy minus, otrzymujemy jeszcze większy minus. 
wiedza autora, erudycja, świetna znajomość wielu ważnych teorii (Andrzej Chwalba) ${ }^{8}$. Zdaniem trzeciego z recenzentów za szczególne cenne należy uznać odwagę przejawiająca się zarówno w podjęciu tematu tak rozległego, jak i w zaangażowaniu się w problematyzację tegoż tematu niepopularnych w naszym klimacie intelektualnym całościowych perspektyw metodologiczno-teoretycznych oraz poczucie odpowiedzialności: $z$ daje sobie bowiem doskonale sprawę z tego, że im bardziej proponowane interpretacje odbiegaja od standardowych, tym lepiej i wszechstronniej trzeba je uzasadnić - i tak stara się postępować (Anna Zeidler-Janiszewska).

\section{Pseudopodstawy aWANSU naukowego}

A jak rzecz przedstawia się w rzeczywistości? Z jednej strony wskażmy, że już formułowano bardziej krytyczne oceny monografii ${ }^{9}$. Z drugiej do zabrania głosu zmusza nas nie tylko autorytaryzm niekompetentnych, a bezwzględnych wypowiedzi wobec środowiska historyków polskich. Zaniepokojenie rodzi niekompetencja i naruszanie w rozprawie habilitacyjnej Jana Sowy podstawowych norm badawczych, rodzące podejrzenie, że mamy do czynienia z habilitacyjną hochsztaplerką ukrywającą

8 Równocześnie, jeden z recenzentów, A. Chwalba, całkowicie dyskwalifikuje wiedzę historyczną Habilitanta zalecając mu zapoznanie się choćby z najnowszymi syntezami dziejów Polski i podręcznikami, gdyż niestety autor [Jan Sowa] $z$ nich nie skorzystał.

9 Oto przykłady kompetentnych, odmiennych od większości pozostałych w ocenie dzieła Jana Sowy wypowiedzi S. Adamkiewicza, Banialuki Pana Sowy, (http://kuznia. art.pl/recenzje/874-fantomowe-cialo-krola-jan-sowa.html), dostęp 24 listopada 2016 r., lub dość sceptyczne, a racjonalnie oceniające kolonialną koncepcję rec. F. BIAŁKA, Realne, czyli polskość, http://nowe-peryferie.pl/index.php/2012/11/realne-czyli-polskosc/, dostęp 23 listopada 2016 r., czy T. Wiśniewskiego, Czyja historia, jaka teoria?, http:// www.stanrzeczy.edu.pl/wisniewski-czyja-historia-jaka-teoria/, dostęp 22 listopada 2012 r. Na przywołanie w tym miejscu zasługują także jednoznacznie krytyczne, a profesjonalne uwagi Izabeli Lewandowskiej-Malec. Pozostawiamy na uboczu teksty, w których dominującym elementem krytyki są różnice światopoglądowe, por. np. J. BrodACKI, Uczony kult cargo albo nieustraszeni pogromcy wampirów. Czytanie Jana Sowy Fantomowe ciało króla, http://www.taraka.pl/uczony_kult_cargo_albo, dostęp 1 kwietnia $2015 \mathrm{r}$. 
uprawianie przez pseudonaukowca pseudonauki ${ }^{10}$. Stoimy bowiem na stanowisku, że procedura habilitacyjna Jana Sowy w najmniejszym stopniu nie dawała podstaw do pozytywnego wniosku, jaki sformułowała Komisja habilitacyjna w składzie: Ewa Kosowska (przewod., UŚ) Kazimierz Krzysztofek (sekret., Szkoła Wyższa Psychologii Społecznej w Warszawie) i członkowie Hanna Gosk (UW) i Ewa Domańska (UAM) oraz recenzenci Andrzej Chwalba (UJ), Przemysław Czapliński (UAM), Anna Zeidler-Janiszewska (SWPS w Warszawie) ${ }^{11}$.

Jak wskazaliśmy, Habilitant podjął się systematycznej i kompleksowej reinterpretacji polskiej historii społecznej, kulturowej, gospodarczej i politycznej ${ }^{12}$. Jan Sowa wielokrotnie powtarza, że nie zamierza szukać nowych faktów z dziejów, ale chce zająć się jedynie rekonfiguracją i reinterpretacją faktów, procesów i zjawisk już opisanych $w$ historiografii. Analiza i reinterpretacja dwustuletniego dorobku polskiej historiografii w zakresie historii społecznej, kulturowej, gospodarczej i politycznej to zadanie niezmiernie ambitne. To dzieło życia dla wybitnej jednostki. A Autor rozprawy habilitacyjnej nigdzie nie określa podstawy swoich badań, jakby nie zdając sobie sprawy, że musi wiedzieć, co stanowi fundament wywodów rozprawy habilitacyjnej. W konsekwencji czytelnik nie wie, jakie fakty podlegają rekonfiguracji i - co najgorsze - nie wie tego sam Habilitant, który bez racjonalnego uzasadnienia uważa, że nie ma obowiązku dokonywać przeglądu całej istniejącej w historiografii literatury na jakikolwiek temat ani tym mniej odwoływać się do niej, wskazując następnie, że do materiału historycznego odwołuję się w takim zakresie, jaki jest konieczny dla lepszego zbadania interesujacych mnie problemów, a nie po to, aby rozstrzygać spory znane z historii polskiej hi-

10 Zauważmy, że autorzy, W. UruszczAK, (Z takim sposobem uprawiania nauki godzić się nie można «SDPIPP» 18/2015, s. 233-255) i J. MATuszewsKI, (Kudrycyzacja, czyli poniewieranie nauki przez biurokrację, «SDPiPP»18/2015, s. 211-231), każdy oddzielnie, już wcześniej zwrócili, choć jedynie marginalnie, uwagę na publikację Jana Sowy. By nie mnożyć bytów ponad potrzebę, przygotowano wspólne stanowisko.

11 Dwóch innych, wcześniej powoływanych na recenzentów badaczy nie dotrwało w Komisji habilitacyjnej do końca jej prac, por. http://www.ck.gov.pl/images/PDF/ Awanse/SowaJan/, dostęp 6 czerwca 2013 r.

12 Swe zadanie określa też mianem - cokolwiek by to miało znaczyć - „rekonfiguracji” bądź „rekonceptualizacji”. 
storiografii ${ }^{13}$. Zwraca tu uwagę rażący circulus vitiosus: projekt naukowy przewiduje - powtórzmy - „reinterpretację" i „rekonfigurację” faktów, procesów i zjawisk już opisanych $w$ historiografii, przy równoczesnym założeniu, że realizator tego projektu owej historiografii, a więc owych „faktów, procesów i zjawisk” znać nie musi! Czy to w badaniach naukowych dopuszczalne? Nic dziwnego, że kompetentny recenzent procedury awansowej musiał stwierdzić, że Habilitant tendencyjnie wybiera materiał historyczny, który ma jedynie dowieść [...] stuszności jego tez oraz teorii, z której $w$ danym momencie korzysta [...] Za pomoca takiego postępowania jest $w$ stanie udowodnić najbardziej absurdalne tezy $y^{14}$. Przypominamy, że mamy tu do czynienia z zakończonym pozytywnym wnioskiem dokumentem (recenzją habilitacyjną), który zgodnie z wymaganiami ustawy ma potwierdzić osiągnięcie naukowe Habilitanta. A tu nikt nie rozstrzygnął, czy podstawą przeprowadzanych przez Habilitanta dywagacji historycznych jest wiedza na poziomie podręcznika licealnego - co uprawnia do ubiegania się o maturę, czy też Jan Sowa przeprowadził na poziomie akademickim niezbędne w postępowaniu habilitacyjnym gruntowne badania nad historiografią.

13 J. SowA, Nota..., s. 300. Nie wiemy, w jaki sposób owa konieczność jest wyznaczana.

14 Uderza niedostatek wiedzy i umiejętności historycznych, A. CHWALBA, Recenzja [habilitacyjna] dorobku naukowego doktora Jana Sowy (19 września 2012). Natomiast drugi z recenzentów, Przemysław Czapliński, w szeregu wypowiedzi sugeruje, że on sam - podobnie jak Habilitant - nie zna i zupełnie nie rozumie problematyki państwa szlacheckiego, którą podejmuje Sowa. Ale nie przeszkadza mu to uznać, że Habilitant sformułował przekonującą tezę o nieistnieniu państwa szlacheckiego, choć udowodnienie istnienia bądź nieistnienia państwa polskiego [...] nie wydaje się rzeczą możliwą; możliwe jest natomiast zaproponowanie takich kategorii badawczych i posłużenie się taka metodologią, która hipotezie nieistnienia nada heurystyczną przydatność. P. Czapliński ostatecznie stwierdza, że Jan Sowa nie tylko analizuje brak państwa, ale także brak króla (s. 6 rec.), co zakrawa na kpiny, bo tak daleko nie posunął się sam Habilitant! Sądzimy, że stwierdzenie, że nie da się ustalić, czy istniało państwo polskie, naukowo kompromituje Recenzenta. 


\section{Pseudopsychoanaliza}

W książce habilitacyjnej Jana Sowy znajdujemy rozważania poświęcone psychoanalizie polskiej przeszłości, których metodologiczną podstawą ma być dorobek kontrowersyjnego francuskiego psychiatry i psychoanalityka, Jacques'a Lacana ${ }^{15}$. To jego koncepcję w y k o r z y stania matematyki do psychoanalizy, wykorzystuje Jan Sowa, wykorzystując Lacanowskie wykorzystanie matematyki do wykorzystania Lacanowskiej psychoanalizy w odniesieniu do rozważań nad systematyczną i kompleksową reinterpretacją polskiej historii społecznej, kulturowej, gospodarczej i politycznej [s. 34], czyli dziejami państwa i społeczeństwa polskiego. Zacytujmy: Mój sposób użycia terminologii psychoanalitycznej można by najtrafniej opisać przy pomocy sytuacjonistycznego pojęcia "przechwycenia” (détournement). Bytby on analogiczny do sposobu wykorzystywania przez Lacana matematyki [s. 360-361]. Sęk w tym, że sposób wykorzystania przez Lacana matematyki poddany został „kastracji” i pozbawiony wszelkiej potencji. Z jednej strony Habilitant, a potwierdzają to i recenzenci, uważa za swoje wyjątkowe osiągnięcie naukowe wykorzystanie Lacanowskiej psychoanalizy dla przeprowadzenia rekonceptualizacji historii: $n a$ szczególna uwage zasługuja moim zdaniem rozdziały, gdzie pojawia się instrumentarium psychoanalizy lacanowskiej [J. Sowa, Autoreferat, s.10-11], analiza Lacanowska świetnie zdaje sprawę z uwikłania jednostki $w$ relacje społeczne [s. 356]. Z drugiej pojawia się już na wstępie zasadniczy problem: krytyka Lacanowskiego nauczania. Weryfikację walorów matematycznych Lacanowskiej teorii znaleźć można w książce A. Sokala i J. Bricot, Modne bzdury ${ }^{16}$. Habilitant o krytyce słyszał, nie pomija jej,

15 Według zwolenników, Lacan zrewolucjonizował teorię i praktykę psychoanalizy. Według krytyków, był szarlatanem, a jego prace to czyste słowolejstwo, A. SoKaL, J. BRICMONT, Modne bzdury: o nadużywaniu pojęć z zakresu nauk ścislych przez postmodernistycznych intelektualistów, Warszawa 2004, s. 31. W wersji francuskiej: Impostures Intellectuelles, angielskiej: Fashionable Nonsense: Postmodern Intellectuals' Abuse of Science (Nowy Jork) lub Intellectual Impostures (Londyn). Por też E. Roudinesco, Jacques Lacan. Jego życie i myśl, Warszawa 2005, ss. 704.

16 A. Sokal, J. Bricmont, op. cit., Rozdział 1: Jacques Lacan, s. 31-48. 
ale unika rzeczowego przedstawienia zastrzeżeń - nie wskazuje czytelnikowi miejsca, w którym Lacan poddany zostaje krytyce, nie odnosi się do uwag charakteryzujących nadużycia metodologiczne, lecz odsyła do c a łej książki [s. 361, przyp. 14].

A szkoda, bo czytelnik powinien wiedzieć, jakie m. in. były intencje autorów Modnych bzdur, przedstawiających nadużycia popełniane przez pewne kategorie postnowoczesnych „amerykańskich i francuskich intelektualistów", konstruujących teorie z błędnym użyciem idei i pojęć naukowych [Modne bzdury, s. 11] $z$ wykorzystaniem nauk ścisłych, bez zrozumienia terminów i pojęć, którymi się posługują. Dalej krytycy m. in. Lacana piszą: Chcieliśmy wyjaśnić, w sposób popularny, dlaczego te wypowiedzi sq absurdalne lub, w wielu przypadkach, po prostu bezsensowne. Pragnęliśmy również omówić kulturowe okoliczności, dzięki którym te dyskursy cieszyly się uznaniem i jak dotychczas nie zostaty zdemaskowane. [...] Piszemy tu o mistyfikacjach, celowo niejasnym języku, błędnym rozumowaniu i nadużywaniu pojęć naukowych [Modne bzdury, s. 10]. I pytają: Czy celem [odwoływania się do nauk ścisłych] nie jest przypadkiem zaprezentowanie jako nadzwyczaj głębokich banalnych obserwacji filozoficznych lub socjologicznych przez ubranie ich w wymyślny żargon naukowy [Modne bzdury, s. 24]. Znajdziemy cechy wypowiedzi pseudonaukowców postmodernizmu: niejasny żargon, niejawne odrzucenie racjonalnego myślenia, nadużywanie języka nauk ścistych jako metafor [Modne bzdury, s. 27] i wskazanie: w sposób oczywisty nie rozumieja pojęć naukowych do których się odwołują i - co ważniejsze - nie podaja żadnych argumentów dowodzących, że pojęcia te znacza cokolwiek $w$ dziedzinie będącej przedmiotem ich badań [Modne bzdury, s. 28]. W odniesieniu do Lacanowskiego posługiwania się matematyką zarzuty są porażające, np.: W tym zdaniu używa czterech terminów $z$ dziedziny analizy matematycznej [...], ale nie zwraca najmniejszej uwagi na ich znaczenie: $z$ matematycznego punktu widzenia to zdanie jest bezsensowne [Modne bzdury, s. 33]. W tym fragmencie Lacan miesza liczby niewymierne z urojonymi [...]. Pojęcia te nie mają ze soba nic wspólnego [Modne bzdury, s. 38], Tutaj Lacan niewątpliwie nabiera czytelników [...] jego „obliczenia” sa czysta fantazja [Modne bzdury, s. 38-39], „matematyka" tego autora jest tak dziwaczna, że nie może przynieść pożytku 
$w \dot{z} a d n e j$ poważnej analizie psychologicznej [Modne bzdury, s. 47]. Czy można w sposób bardziej zdecydowany zdyskredytować Lacanowską matematykę?

Jan Sowa udaje, że nic się nie stało, wyjaśniając, że na zarzuty odpowiedział już sam - zmarły niemal 20 lat przed ich sformułowaniem - Jacques Lacan ${ }^{17}$, gdyż był doskonale świadom nie w pełni technicznego, w pewnym sensie "metaforycznego" sposobu wykorzystywania przez siebie matematyki [s. 361 ${ }^{18}$. Innymi słowy mówiąc, chodzi tu nie o techniczne, choć częściowo techniczne, metaforyczne, acz niezupełnie metaforyczne wykorzystanie matematyki. Użycie jako wyjaśnienia zwrotu „nie w pełni techniczny”, „w pewnym sensie «metaforyczny»” sposób wykorzystywania matematyki zdecydowanie sugeruje, że Jan Sowa nie wie, choć powinien, w jaki sposób jest ta matematyka wykorzystywana ${ }^{19}$. Dodatkowo całe wyjaśnienie uzupełnione jest cytatem $\mathrm{z}$ Lacana, który pisał, że: moje przechwycenie $e^{20}$ algorytmów matematycznych [...] może być uzasadnione, tylko jeśli zrezygnujemy z pretensji do jakiegokolwiek automatyzmu w jego kolejnych zastosowaniach, co Jan Sowa wyjaśnia: Z zastrzeżenia Lacana wynika bowiem jasno, że nie chodzi o zniekształcenie, ale o rezygnacje $z$ użycia systemowego i globalnego danego symbolu $w$ całej składniowej rozciągłości języka, którego jest częścia, na rzecz użycia bardziej punktowego i lokalnego [s. 361]. Jeśli dobrze rozumiemy wypowiedź obu autorów, to sugerują oni, że przyjmowania przez nich zasada, nie

$17 \quad 1901-1981$.

18 Zwracamy uwagę, że wśród zarzutów znajduje się nadużywanie języka nauk ścisłych jako metafor [Modne bzdury, s. 27]. A więc odpowiedzią Lacana było - zdaniem Habilitanta - uznanie trafności zarzutu!

19 A. SoKAL, J. Bricmont, [op. cit., s. 47] wskazują na posługiwanie się strategią ani/ani. U Sowy np. wskazanie, że zajmuje się on okresem od przełomu średniowiecza i nowożytności do końca XIX wieku, [s. 42], ale nie jest to książka historyczna: To w całości tylko i wyłacznie książka o współczesności oraz nowoczesności [...] Nie jest to jednak książka o współczesności i nowoczesności... [s. 42].

${ }^{20} \mathrm{~W}$ oryginale détournement, co oznacza jednak 'odwrócenie' (algorytmu), jak w przekładzie A. SoKAL, J. Bricmont [op. cit., s. 39]. 
jest zasadą, ale nią tylko bywa, a zmatematyzowanie psychoanalizy nie musi być jej zmatematyzowaniem, tylko jakąś metaforą ${ }^{21}$.

Zauważmy jeszcze, że Lacan zgodnie ze swoim zwyczajem stara się celowo komplikować wypowiedzi przez odwoływanie do terminologii stosowanej w wyższej matematyce, a więc zazwyczaj obcej zwykłemu śmiertelnikowi. Najwidoczniej to go bawiło, przeto nie budzi zdziwienia, że - odwołujemy się do ustalenia Jana Sowy - francuski psychoanalityk dla określenia linii (toru czyli trajektorii) poruszania się przez poddawany psychoanalizie podmiot wobec przedmiotu pożądania sięgnął po termin torus. Sam torus, który najprzystępniej ilustrować kształtem obarzanka lub dętki [dwuwymiarowa powierzchnia obrotowa zanurzalna w przestrzeni trójwymiarowej, powstała przez obrót okregu wokót prostej leżącej w tej samej płaszczyźnie i nieprzecinającej go] jest zupełnie niepotrzebny przy charakterystyce ruchu obiektu wobec przedmiotu pożądanego. Prościej byłoby napisać, że pożądający „biega” wokół pożądanego przedmiotu, nie mogąc się doń zbliżyć, ani odeń oddalić. Ale to już by nie było ani takie mądre, ani takie głębokie.

J. Sowa odwołuje się do Lacanowskiej identyfikacji podmiotu psychoanalizy z niezupełnie zrozumiałych powodów. Pisze bowiem, że choć dokonane przezeń przechwycenia pojęć Lacana, przebiegaja dokładnie wedtug tej samej reguły [s. 362], to jednak - wbrew twierdzeniu Lacana, że torus ten istnieje naprawdę $i$ właśnie on jest struktura neurotyka poddawany przezeń psychoanalizie neurotyczny podmiot szlachta nie musi mieć s t r u k t u r y w kształcie torusa (dętki). Ale może? Zdaniem Habilitanta Lacan przywołuje torusa dla zobrazowania ruchu: opisuje trajektorię neurotycznego podmiotu, który krąży wokół nieodstępnego a popychany przez pragnienie i domaganie [s. 362]. Jednocześnie - powtórzmy - torus mógłby, choć nie musi, charakteryzować s t r u k t u r ę

${ }^{21}$ Habilitant jednak szybko zapomina o tych zastrzeżeniach i pisze: Podobny sens ma sięganie przez Lacana do matematyki czy topologii, których użycie nie jest retorycznym ozdobnikiem, ale służyć ma budowaniu fundamentów całego systemu [s. 380]. Co będzie z tym, opartym na metaforze matematycznym fundamentem, gdy przypomnimy sobie, co o matematyce Lacanowskiej sądzą matematycy? 
stanu szlacheckiego ${ }^{22}$. Czy w tym momencie trafnie nasuwa się nam przypuszczenie, że Jan Sowa nie rozumie tego, co pisze?

I dalej: zadanie analityka to bombardowanie Realnego metaforami, które pozwola analizowanemu poddać symbolizacji coś, co wcześnie znajdowało się całkowicie poza jakimikolwiek strukturami symbolicznymi i jeśli mogło jakoś wyrazić swoja prawdę, to tylko pod postacia bezsensownego symptomu [s. 364]. Zatem planuje on przeprowadzić eksperyment bombardowania Realnego w taki sposób, by analizowany mógł poddać symbolizacji „coś”. Niestety, zapomniał ustalić, kim (czym) jest ów analizowany. Raz bowiem czytamy o badaniu historycznych procesów, które uksztattowały polska podmiotowość [s. 41], gdzie indziej Habilitant pisze, że zajmować się będzie psychoanalityczna rekonceptualizacją rozbiorów [s. 34], czytamy też o psychoanalizie sarmatyzmu [s. 39-40], o poddaniu się psychoanalitycznej interpretacji przez przypadek Rzeczypospolitej Obojga Narodów [s. 354], że dotyczy ona szlachty [s. 362] czy interpretacji losów I Rzeczypospolitej i - szerzej - regionu Europy Środkowo-Wschodniej [s. 365], także nowożytnej historii Polski [s. 382], demokracji szlacheckiej [s. 392]. Habilitant wskazuje również na zamiar opisania $w$ kategoriach psychoanalitycznych procesu konstrukcji szlacheckiego podmiotu [s. 403], zajmuje się psychoanalitycznym modelem ładu westfalskiego [s. 426], stwierdza, że opis w kategoriach psychoanalitycznych dotyczy podmiotu postkolonialnego [s. 442], że kategorie psychoanalizy jak najbardziej nadaja się do opisu funkcjonowania $i$ wewnętrznej dynamiki tego tłumu, czyli „polskiej szlachty oraz jej państwa" [s. 358] ${ }^{23}$. Z kolei na s. 364 czytamy, że przedmiotem analizy ma być sytuacja Polski oraz Europy Wschodniej, by w końcu

22 Zacytujmy całą wypowiedź: Jeśli więc postaram się wskazać, że polska szlachta $w$ geście typowym dla neurotyka zidentyfikowała $\Phi$ i $D$ (brak $w$ Innym z jego domaganiem), sprowadzając tym samym swój fantazmat do popędu (\$ $\diamond D)$, nie oznacza to wcale, że wewnętrzna struktura szlachty jako podmiotu musi przyjmować kształt torrusa chociaż Lacan $w$ seminarium L'identification tak właśnie opisuje trajektorię neurotycznego podmiotu, który krąży wokół nieodstępnego [niedostępnego?] a popychany przez pragnienie i domaganie (s. 362).

23 Intrygującą wydaje się psychoanaliza nieistniejącego państwa (wg J. Sowy - trupa). 
poznać, na czym ma polegać psychoanaliza Polski szlacheckiej [s. 390]. Ale czy można racjonalnie dokonywać psychoanalizy bez ustalenia analizowanego? Psychoanalizy nie-bardzo-wiadomo-czego?

\section{Pseudokompetencja}

Jako znaczące osiągnięcie Fantomowego ciała króla, zarówno w recenzjach habilitacyjnych, jak i w innych wypowiedziach, traktuje się rozbudowane założenia metodologiczne książki. Sam Autor wskazuje na uwzględnienie przez siebie nowego paradygmatu metodologicznego [s. 106], na wykorzystanie metodologii długiego trwania [s. 28-29], na uprawiany geograficzny holizm [s. 29], unidyscyplinarność, którą odbieramy - nie wiemy, czy słusznie - jako metodologiczną wszechstronność [s. 30] $]^{24}$, przyjęcie perspektywy interpretatora, a nie odkrywcy w posługiwaniu się socjologią historyczną [s. 50], odwołanie się do wskazówki metodologicznej niezwykle rzadkiego zdarzenia [s. 107-108], oraz do wieloczynnikowego modelu wyjaśniania [s. 169], sięgnięcie do psychoanalizy jako jednej z metod wpisujących się $w$ szerszą rame hermeneutyki podejrzeń [s. 355]. Mówi o przepuszczeniu sarmatyzmu przez filtr teorii postkolonialnej [s. 38] przy równoczesnym wskazaniu na konieczność poszukiwania psychospołecznych wyjaśnień [s. 475], wykorzystania metod teorii postkolonialnej [s. 438]. Nie brak też bardziej

24 Która w końcu okazuje się nie pomysłem Autora, lecz parafrazą koncepcji I. Wallersteina [s. 106], o której mówiono już w literaturze polskiej parę lat przed deklaracją Jana Sowy, (por np. Perspektywy badań nad kulturą, red. R. KLuszczyński, A. ZEIDlen-JaniszewsKa, Łódź 2008, s. 7-8. Dodajmy, że z jednej strony buńczucznie deklarując przekraczanie, czy nawet zniesienie granic między dyscyplinami naukowymi, Jan Sowa (s. 30), zmyka z tej strefy unidyscyplinarności czy postdyscyplinarności i chowa się „w krzakach” kwestionowanego podziału dyscyplin naukowych, gdy tylko zaczyna mu się palić grunt pod nogami: nie jestem historykiem, ani nigdy nie aspirowałem do instytucjonalnego rozpoznania jako historyk [...] jestem kulturoznawca $i$ socjologiem (J. SowA, Nota..., s. 300. Odmiennie odbierają jego wystąpienie czytelnicy: Jako znakomity historyk Sowa... czytamy w rec. K. Zajasa (s. 69); że Sowa jest historykiem, uważa recenzent P. Czapliński. 
generalnych odniesień metodologicznych ${ }^{25}$. Jednak dla rozważań Jana Sowy podstawową jest koncepcja nieistnienia państwa polskiego po 1572 r., która ma być wynikiem wykorzystania teorii (?) opisanej przez Ernsta Kantorowicza i Claude'a Leforta [s. 37, 44] ${ }^{26}$. Nimi przeto zająć się trzeba przede wszystkim. Jeśli bowiem okaże się, że to fundamentalne założenie rozprawy jest dotknięte błędem, to pomyłką okaże się pomysł fantomowego ciała króla, a więc praktycznie wszystko, czym zajmowano się w książce.

Jest co prawda alternatywa: upadek koncepcji fantomowego ciała króla można bagatelizować, sugerując, iż niezależnie od tego, pozostałe rozważania Jana Sowy mają jakąś wartość. Jeśli tak, to trzeba będzie przyjąć, że fundament wywodu wcale nie jest fundamentem, a jedynie bezsensownym wtrętem. Wówczas przyjdzie nam rozważyć kolejne fundamenty rozprawy habilitacyjnej.

Jan Sowa wprowadza fantomowe ciało króla do dziejów państwa szlacheckiego: Spróbujmy wykorzystać koncepcję dwóch ciał króla wraz z jej aparatem pojęciowym do opisania sytuacji I Rzeczypospolitej [s. 236]. Ma przy tym świadomość, że przykłada do państwa polsko-litewskiego standardy poniekąd zewnętrzne ${ }^{27}$ [...] Jednak - uważa - to postępowanie uprawnione [s. 237], gdyż:

- pozostajemy zasadniczo ${ }^{28}$ w obrębie tego samego kręgu kulturowego [s. 237];

- porównujemy środkowoeuropejskie praktyki społeczno-polityczne do sytuacji panującej $w$ tym samym czasie $w$ innym państwie

25 Przywoływana jest współczesna metodologia nauk społecznych [s. 168].

26 Pisze on expressis verbis, że interpretuje fakt urojonej państwowości w świetle Ernsta Kantorowicza teologiczno-politycznej teorii dwóch ciał króla [s. 38].

27 Niepokoi maniera zbyt częstego formułowania wypowiedzi, w których zawiera się jej samozaprzeczenie, np. standardy poniekąd zewnętrzne są, czy nie są zdaniem Jana Sowy standardami, są czy nie są zewnętrznymi?

28 Nie wiemy czy zasadniczo ma wskazywać, że pozostajemy, ale chwilowo, lub na ogół, czy że zasadniczo w obrębie, ale niezupełnie, czyli częściowo poza; czy może; zasadniczo tego samego, ale tylko w znacznym stopniu? A może - równie dobrze - odwoływać się do kardynalnego charakteru tezy. 
europejskim o podobnym - przynajmniej na pierwszy rzut oka ${ }^{29}$ ustroju monarchicznym [s. 237] ${ }^{30}$;

- dodatkowo doktryna dwóch ciat króla mówi właśnie o tym, jak kształtowała siępolityczno-prawna forma państwa [s. 237]. A to już totalna bzdura!

Autor chce odpowiedzieć na pytanie, dlaczego $w$ Polsce zmagania ${ }^{31}$ $z$ nowoczesna forma państwowo-społeczna nie przyniosły zadowalajacego rezultatu i przyjmuje bez jakiegokolwiek uzasadnienia, że trudno więc o lepsze [niż doktryna dwóch ciał króla] narzędzie konceptualne, żeby zdiagnozować istotę porażki poniesionej na tym polu przez Polskę (rozbiory) [s. 237].

Zauważmy błąd zasadniczy, który przesądza o walorach rozumowania. Nic nie wiadomo, a Autor na to nie zwraca uwagi, czy istnieje jakaś relacja, która powoduje, że sposób przyznania państwu podmiotowości prawnej, tak bowiem Jan Sowa pojmuje - pozostawiamy w tym miejscu na uboczu trafność tej interpretacji - drugie ciało króla, może w jakikolwiek stopniu wpływać na zmagania $z$ nowoczesna forma państwowo-społeczną. Przygotowujący swą habilitację Jan Sowa widocznie takie założenie przyjmuje, uważając, że jakiś związek między kształtowaniem się koncepcji osobowości prawnej (podmiotowości) państwa a jego zdolnością modernizacyjną istnieje. Nie udało się nam w rozprawie znaleźć jakiegokolwiek próby uzasadnienia tej hipotezy, a nie jest ona w najmniejszym stopniu oczywista ${ }^{32}$. Czy bez przynajmniej uprawdopodobnienia tego podstawowego założenia można formułować racjonalne

29 Kolejne zastrzeżenie zmieniające w niejasny sposób wartość wypowiedzi. Czy chodzi tu o sugestię, że po chwili refleksji owego podobieństwa już nie będzie?

30 Choć u E. Kantorowicza znaleźć można ważką uwagę: „Ciało wspólnotowe królestwa" miało więc w Anglii unikatowe, konkretne znaczenie w znacznie większym stopniu niż miało to miejsce w innych królestwach europejskich, s. 353. W historiografii polskiej wskazuje się na recepcję wzorów węgierskich, por niżej przyp. 32.

31 Cokolwiek by to miało znaczyć!

32 Tym bardziej, że proces kształtowania się w Polsce podmiotowości prawnej państwa został opisany, bez odwoływania się do koncepcji dwóch ciał królewskich, por J. DĄвrowski, Korona Królestwa Polskiego w XIV w., Wrocław-Kraków 1956, oraz polemiczna recenzja K. Grzy bowskiego, 'Corona regni' a 'Corona Regni Poloniae', «CPH» 9.2/1957, s. 299-331. Na to Jan Sowa nie zwraca uwagi. 
wnioski? Czy ot, tak sobie, do wycięcia ślepej kiszki można wykorzystać dentystyczne i do tego popsute kleszcze ekstrakcyjne?

Powtórzmy: mamy do czynienia z hipotezą, że istnieje związek między koncepcją osobowości prawnej państwa a możliwościami reformy ustroju państwa. Ale nic nie wiadomo, na jakiej podstawie ją sformułowano $^{33}$. Spróbujmy zatem ustalić konsekwencje tej hipotezy oraz efekt konieczności odrzucenia fundamentalnego dla rozprawy habilitacyjnej przypuszczenia o możliwości wykorzystania koncepcji dwóch ciał króla do analizy zdolności modernizacyjnych państwa i społeczeństwa polskiego.

Jan Sowa, przy aplauzie recenzentów, uważa, że upadek I Rzeczypospolitej nastąpił w 3 lata po jej powstaniu, w 1572 r., z chwilą, gdy umarł ostatni władca dziedziczny: Taki też był los I Rzeczypospolitej: śmierć ostatniego dziedzicznego monarchy $w$ historii polskiego państwa

33 Nie jest to jedyna sytuacja, gdy w habilitacji pomija się uzasadnienie formułowanej tezy. Podobnie, exempli causa za „jedną z podstawowych i trwałych cech kontynentu europejskiego" uznano linię Łaba - Dunaj [s. 365 i n.] Według J. Sowy jest to linia trwała, która „zawsze powraca na swoje miejsce” [s. 365]. Odwołując się do kategorii Lacana, nasz Autor uznaje tę linię za „coś Realnego jako najgłębsze uporządkowanie pewnych relacji strukturalnych” [s. 366]. Jest to „element” który funkcjonuje jako zwornik całości [s. 366], wzdłuż [granicy na Łabie] ... systematycznie różnicuje się symboliczny porzadek kontynentu [s. 366]. Granicę tę Habilitant uznaje za uporczywe trwanie pewnej formy [s. 369]. Pisze, że powinniśmy mówić o automatyzmie granicy na Łabie-Dunaju czy tė̇ o uporczywym przymusie powtarzania tej granicy (s. 371). Wywód o granicy na Łabie-Dunaju ilustrowany jest „dowodem matematycznym” konstruowanym na przykładzie rzutów monetą. Sęk w tym, że Autor nie zauważył, że zajmując się Lacanowskim absolutnym prymatem znaczących (form) odniesionym do psychiki ludzkiej, próbuje odnieść ją do faktu historycznego, czyli treści - nie formy! Sam „wywód matematyczny” jest wątpliwy co do swej wartości poznawczej. Kodowanie wyników rzutu monetą przesądza jedynie sposób zapisu, a więc formę. Nie ma ona żadnego wpływu na wynik rzutów monetą, które niezmiennie zachowują charakter losowy, a więc niezależny od języka czy też woli rzucającego. Zamieszczenie w elukubracjach o granicy na Łabie-Dunaju wywodu odnoszącego się do psychiki człowieka i próba nadania mu charakteru jakiegoś znaczącego argumentu w dyskusji nad historycznym znaczeniem granicy na Łabie i Dunaju w Europie, to manipulacja, obliczona na sui generis zauroczenie czytelnika pseudogłębią wiedzy. Gdyby jeszcze Habilitant wyprodukował owe matematyczne wywody samodzielnie, to można by ewentualnie docenić jego wysiłek, ale on przepisał cudze. 
była też śmiercia tego państwa jako takiego [s. 240]. W tym momencie (Habilitant odważnie, acz w sposób nieprzemyślany zmienia datę śmierci Rzeczypospolitej $^{34}$ ) zniknęło państwo, stało się bowiem fantomem ${ }^{35}$, zjawą, która realnie nie istnieje - umarłe państwo stało się duchem. Pomysł porównania „realnie” istniejącego państwa, które nie istnieje tylko „Realnie"36, do neurologicznego złudzenia organizmu ludzkiego (realnie nieistniejąca kończyna jest odczuwana „Realnie”) to nieporozumienie. Czym uzasadniona ta konstrukcja, tego nie wiadomo. Jakiegokolwiek uzasadnienia brak.

Do tego budowana jest ona na kolejnym nieporozumieniu. Podstawowe założenie Jana Sowy, że Zygmunt II August był ostatnim dziedzicznym królem w Polsce, jest całkowicie błędne. Koronę syn Zygmunta Starego zawdzięczał nie prawu dziedziczenia, lecz aktowi elekcji (była to elekcja vivente rege), która miała miejsce na sejmie w 1530 r. Była to elekcja warunkowa, gdyż objęcie tronu mogło nastąpić dopiero po zaprzysiężeniu praw Królestwa przez pełnoletniego elekta. Co więcej, z elekcji pochodziła władza przodków Zygmunta Augusta, wszystkich synów Kazimierza Jagiellończyka - Olbrachta, Aleksandra i Zygmunta Starego (stryjów i ojca ostatniego z Jagiellonów). Kolejny z synów, kardynał Fryderyk Jagiellończyk został interrexem (regentem Królestwa) po śmierci ojca. Elekcja była podstawą panowania Władysława Warneńczyka i jego brata, a także założyciela dynastii - Jagiełły. Jakby tego było mało - wbrew twierdzeniu Sowy - już w czasach piastowskich elekcja była decydującym czynnikiem procedury obsadzania tronu. $\mathrm{Z}$ formalnego punktu widzenia jedynym okresem, w którym obowiązywało dziedziczenie tronu, były czasy andegaweńskie. To na podstawie

34 Gdybyśmy mieli podać dokładny moment, w którym do tego doszło, byłyby to obrady konwokacji warszawskiej między 6 a 29 stycznia 1573 roku [J. S., s. 240]. Czyli państwo - zdaniem Jana Sowy - istniało jednak rok dłużej?

35 Tu odwołanie do zjawisk medycznych.

36 „Realnie” (z dużej litery) oznacza nierealnie: Gdy używam słowa „Realne” $w$ znaczeniu, jakie nadał mu Jacques Lacan, pisze je z dużej litery dla odróżnienia od "realnego" $w$ sensie „rzeczywistego”. To istotne, ponieważ dla Lacana „rzeczywistość" wcale nie była tożsama $z$ „tym, co Realne”, a konstytuowała się nawet w pewnej mierze poprzez zaprzeczenie Realnego. [s. 39 przyp. 39], co więcej: Realne to to co niemożliwe [s. 386 przyp. 50]. 
układów sukcesyjnych i umowy budzińskiej wybrano i powołano na tron nową dynastię, przyznano jej prawa dziedziczne, choć początkowo tylko w linii męskiej ${ }^{37}$. Można by zatem wskazać, że Habilitant popełnił błąd, nie dostrzegając, że dziedziczność w czasach piastowskich, jak i jagiellońskich była „fantomem”, co najwyżej współoddziałującym na dominującą przy obsadzie tronu elekcję. Błąd jest rzeczą ludzką i każdemu przydarzyć się może. Choć naukowe ustalenia dyskwalifikuje.

Ale tu nie ma błędu. Sprawa przedstawia się gorzej: Jan Sowa jest nieuczciwy. Kilka stron dalej (s. 243) pisze wyraźnie, że to: koniec dynastii Piastów oznacza faktyczny początek elekcji królów polskich, a więc śmierć Zygmunta Augusta nic nie zmieniła ${ }^{38}$. Konstatacja nie ma jednak żadnego znaczenia, gdyż taka interpretacja, chociaż częściowo uzasadniona, nie ujmuje jednak istoty przełomu, jakim było pierwsze wielkie bezkrólewie $w$ latach 1572-1573. Habilitant zatem za pomocą odpowiedniej interpretacji chce zmieniać fakty (zdarzenia): wiedząc, że Zygmunt August nie był ostatnim dziedzicznym władcą, (a nie był w ogóle dziedzicznym władcą!), dokonuje manipulacji, w wyniku której ten monarcha ma okazać się ostatnim dziedzicznym władcą. Ponadto wodzi czytelnika za nos uznając, że dla ujęcia istoty problemu (istota przełomu) już nie jest istotne, czy Zygmunt August był albo nie był ostatnim dziedzicznym władcą Rzeczypospolitej. Bowiem „śmierć” państwa szlacheckiego przekształcenie się jej w królewski fantom - miała w rzeczywistości zupełnie inną przyczynę. Otóż dla istnienia bądź nieistnienia państwa - kontynuujemy referowanie stanowiska J. Sowy - znaczenie ma nie dziedziczność, a jedynie królewska Godność, której właśnie następcy ostatniego Jagiellona zostali pozbawieni ${ }^{39}$. Jednak mechanizmem odbierającym godność królowi było nic innego, jak pupilla libertatis polskiej szlachty - wolna elekcja (s. 244). Zatem czynnikiem decydującym znowu

37 Wykorzystujemy tu wiedzę podręcznikową.

38 Habilitant nie wie, że prawa dziedziczne przysługiwały Andegawenom.

39 Zdaniem Habilitanta spośród władców I Rzeczypospolitej jedynie Zygmunt August darzony był powszechnym szacunkiem i estymą (s. 244). Co jest podstawą tego twierdzenia-nie ujawnia. 
ma być owa niedziedziczność, choć jej szkodliwość przejawiać się zaczyna dopiero po śmierci Zygmunta Augusta ${ }^{40}$.

Powyższe zastrzeżenia nie mają jednak znaczenia, gdyż mimo zakwestionowania swej wypowiedzi Autor ostatecznie uważa, że to elekcja było przyczyną zniknięcia państwa: Za pierwszym razem szlachta podeszła do tego poważnie i z namaszczeniem. Bardzo szybko jednak spotkania na polu elekcyjnym na warszawskiej Woli zaczęły przypominać prowincjonalny jarmark pełen przekupek targujących się o cenę jajek i ziemniaków, pomiędzy którymi szwendaja się żebracy, pijacy i włóczędzy. Wymóg jednomyślności osiągano przy pomocy gróźb i przekupstw, nie stroniąc od fizycznej przemocy. Na przełomie XVII i XVIII wieku elekcje stały sie całkowita farsa [s. 244-245]. Gdyby traktować wypowiedzi Jana Sowy serio, to należałoby uznać, że skoro do pierwszej elekcji po śmierci Zygmunta Augusta szlachta podeszła poważnie i z namaszczeniem, to nie mogło to wpłynąć na likwidację Rzeczypospolitej. Czyli nie rok 1572 winien oznaczać „śmierć” szlacheckiego państwa. Nastąpi to jednak bardzo szybko i - przypomnijmy: Na przełomie XVII i XVIII wieku elekcje stały się całkowita farsą. Czyżby Jan Sowa skłaniał się ku temu, że Rzeczypospolita zginęła sto lat później niż sam ustala: dopiero na przełomie kolejnych stuleci?

Przedstawienie pola elekcyjnego jako prowincjonalnego jarmarku to mający deprecjonować elekcję chwyt demagogiczny. Chyba, że Jan Sowa jest przekonany, że decyzję elekcyjną podejmował zebrany na polu elekcyjnym szlachecki „motłoch”. Wówczas jednak brak najistotniejszych procedur aktu, który dokonywał sejm zwany elekcyjnym ${ }^{41}$. Najpierw, obradujący w „szopie” senat uzgadniał swe stanowisko co do osoby kandydata, przekazywane następnie do rozważenia otaczającej senat izbie poselskiej. Jeśli stanowisko uzgodniono, wówczas zwracano się do zgromadzonej województwami szlachty z prośbą o akceptację

40 Autor nie wypowiada się, czy równie fantomowym zjawiskiem było elekcyjne Cesarstwo Rzymskie Narodu Niemieckiego lub mające tron obsadzany w drodze elekcji państwo watykańskie.

${ }^{41}$ Por J. DzięGielewski, Sejmy elekcyjne, elektorzy, elekcje 1573-1764, Pułtusk 2003. 
elekta. Tyle o procedurze, która niejednokrotnie była naruszana, jednak niezależnie od tego, do wersji Jana Sowy zdecydowanie nie pasuje.

Inną sprawą wyniki elekcji. Po pierwsze - co już dawno stwierdzono, jeśli tylko była taka możliwość, wynik elekcji odpowiadał postulatom dziedziczenia. Oczywiste, że po bezpotomnej śmierci Zygmunta Augusta, Henryka Walezego, Stefana Batorego trudno było o kandydatury ich zstępnych. Jednak Henryk miał ożenić się z siostrą Zygmunta Augusta - Anną Jagiellonką, wybraną w końcu na króla Polski (1575 r.), a Batory, jak Jagiełło, został wybrany na męża królowej ${ }^{42}$. Ale nie zostali założycielami nowej dynastii. Kolejnym następcą wybrano siostrzeńca ostatniego Jagiellona - Zygmunta III. Po nim - kolejno dwóch Zygmuntowiczów, z których żaden nie zostawił następcy ${ }^{43}$. Zastanówmy się w końcu: czy można wykazać, że efekty następstwa prokreacji dynastycznej będą politycznie korzystniejsze od wyników elekcji? Czy też mielibyśmy się skłaniać ku tezie, że - z perspektywy stuleci - dostrzegamy „lepszego” kandydata niż ten, któremu elekcja powierzyła tron ${ }^{44}$ ?

Dla „śmierci” państwa w ujęciu Sowy ważniejsza jest być może proponowana przezeń, acz niekonsekwentnie, alternatywa. Habilitant uważa niekiedy, że to nie zasada elekcji prowadziła do upadku Rzeczypospolitej, lecz pozbawianie króla „Godności”: Mechanizmem odbierającym godność królowi było nic innego, jak pupilla libertatis polskiej szlachty - wolna elekcja. [...] Godność przyszłych królów podważat już sam przebieg procedury elekcji. [s. 244]. Dodatkowym upokorzeniem dla każdego wybranego monarchy był wstępny szantaż, z jakim występowała szlachta: warunek koronacji stanowiło złożenie przez króla przysięgi dotyczacej przestrzegania artykułów henrykowskich. [s. 245], królowie rozpoczynali swoje panowanie od symbolicznego upokorzenia [s. 246]. To arbitralnie

42 Nawiązaniem właśnie do praw dynastycznych jest ożenek z Anną Jagiellonką.

43 Jedyna elekcja (pomijamy tu wydarzenia z 1764 r.), która odrzuciła zstępnego zmarłego króla dotyczyła potomków Jana Sobieskiego. Ci jednak robili wszystko, by im urzędu głowy państwa nie powierzono.

${ }^{44}$ W epoce wolnych elekcji wielokrotnie obsadzano na polskim tronie pretendentów, którzy w wyraźny sposób dążyli przede wszystkim do realizacji swoich własnych partykularnych interesów, w oczywisty sposób osłabiając przy tym Rzeczpospolita [s. 352]. Nie rozumiemy, czym mają być partykularne interesy pretendenta: to osobiste interesy? 
formułowane twierdzenia nijak się mają do historycznej rzeczywistości. Historiografia podkreśla zdecydowanie, że „godność” w rozumieniu poczucia własnej wartości i oczekiwania szacunku dla samego siebie była przymiotem, której polskiego monarchy elekcyjnego nie wolno było nawet próbować pozbawiać. Można było królowi się przeciwstawiać, ale próby poniżania Majestatu spotykały się ze zdecydowanym protestem ${ }^{45}$.

Autor nie wie, choć mógł i powinien wiedzieć, że Artykuły henrykowskie to przygotowany dla króla-obcokrajowca, nieznającego polskiego systemu ustrojowego, regulamin funkcjonowania urzędu głowy państwa. To formalne opisanie kształtującego się od lat i realnego ustroju. Czy można się dziwić, albo czynić zarzut $\mathrm{z}$ tego, że od sprowadzonego z zagranicy monarchy, pochodzącego z dynastii, która właśnie buduje monarchię absolutną (przypomnieć też warto noc św. Bartłomieja), oczekiwano, że zatwierdzi przysięgą tak, jak to czynili jego poprzednicy, przestrzeganie praw kraju, w którym ma panować? Przysięga koronacyjna nie jest niczym nadzwyczajnym i nie zawiera w sobie niczego poniżającego. Stosowana była i jest po dziś powszechnie, zawierając $\mathrm{m}$. in. zobowiązanie koronowanego do przestrzegania prawa. Dziś nie przynosi degradacji godności papieża, królowej angielskiej ${ }^{46}$, ani żadnej przysięgającej przy obejmowaniu urzędu głowy państwa osoby.

Jednak konkluzja Sowy wynika z następnego nieporozumienia. Otóż powołuje się on na Kantorowicza, nie dostrzegając, że ten ostatni posługuje się „godnością" w zupełnie innym, niż chce Habilitant, znaczeniu. Godność to nie estyma, czyli szacunek, lecz wskazanie na urząd - w tym przypadku królewski ${ }^{47}$. Wszelką wątpliwość $\mathrm{w}$ tym względzie rozwiewać winien użyty zwrot: „Godność albo imperium” [Kantorowicz, s. 352].

45 Por np. Robert I. Frost, Pełen uniżoności brak szacunku: problem władzy królewskiej w Rzeczypospolitej Obojga Narodów za panowania Wazów, 1587-1668, Warszawa 2010, s. 187-210. Powołujemy przekład angielskiego wydania z 2001 r. The Polish-Lithuanian Monarchy in European Context, c. 1500-1795, red. R. ButTerwick.

$46 \mathrm{Na}$ przywiązywanie dziś wagi do treści przysięgi koronacyjnej króla Anglii wskazuje toczony spór o jej religijny charakter.

47 U Kantorowicza odnotowano także odpowiednie odniesienie do godności-urzędu papieża czy biskupa, E.H. Kantorowicz, Dwa ciała króla. Studium ześredniowiecznej teologii politycznej, Warszawa 2007, s. 313 i n. 
Odwołując się do błędnej argumentacji, Jan Sowa nie rozumie przedstawianej w monografii E. Kantorowicza konstrukcji dwóch ciał króla ${ }^{48}$. Jednym z nich jest ciało fizyczne, śmiertelne. Drugie ciało - błęd ny m zdaniem Habilitanta - to osoba prawna, państwo. Natomiast w książce Dwa ciała króla stwierdza się, że Tenens dignitatem est corruptibilis. DIGNITAS tamen semper est, non moritur [Kantorowicz, s. 344] ${ }^{49}$ : drugie ciało, które nigdy nie umiera, to właśnie DIGNITAS, godność, czyli urząd królewski. To kardynalne nieporozumienie pozbawia koncepcję Sowy jakiejkolwiek racjonalnej podstawy: nie wolno mu - jeśli chce wywodzić konsekwencje z teorii dwóch ciał króla - mówić o nieistnieniu państwa, lecz co najwyżej o nieistnieniu urzędu królewskiego w państwie szlacheckim. A tego niezależnie od przyjętej metody chyba nawet Habilitant zrobić nie potrafi.

Zwróćmy uwagę, że teoria „dwóch ciał króla” i „związana z nią koncepcja «jednoosobowej korporacji»” to „twór czysto angielski” [Kantorowicz, s. 352]. Zdaniem tego uczonego teoria ta „była praktycznie nieobecna na Kontynencie" [Kantorowicz, s. 353], a więc także nie była znana w Polsce. Królestwo Polskie u schyłku średniowiecza i w czasach nowożytnych nie było „jednoosobową korporacją” utożsamianą z królem jako ciałem politycznym, lecz stanowiło Corpus Regni, którego elementami składowymi, bez cienia wątpliwości, były obok króla, rada królewska (senat) i szlachta ${ }^{50}$. W żadnym razie osobowość prawna Królestwa Polskiego nie wyczerpywała się w ciele politycznym króla, czyli królewskim urzędzie (godności). Przeciwna temu teza głoszona przez Habilitanta wymagałaby dowodów źródłowych, których w pracy nie sposób znaleźć.

48 Fatalnej omyłki nie dostrzegli też recenzenci, zachwycając się wykorzystaniem przez Habilitanta koncepcji.

49 Por. ibidem, rozdz. Rex instrumentum Dignitatis i uwagi o nierozróżnianiu między officium i dignitas, s. 304-306. To samo o urzędzie papieskim: tenens papatum vel dignitatem est corruptibilis, papatus tamen, dignitatis vel imperium semper est, ibidem, s. 306 przyp. 239.

50 Por K. Grzy воwsкi, Teoria reprezentacji w Polsce epoki odrodzenia, Warszawa 1959, s. 10 i n. 
Rażący błąd Habilitanta, wynikający z fałszywej hipotezy, że Polska za Jagiellonów, jak Anglia, to wyłącznie „polityczne ciało króla” czyli „jednoosobowa korporacja”, demoluje całą koncepcję rozprawy habilitacyjnej. By nie było wątpliwości, zacytujmy: $Z$ punktu widzenia prawno-instytucjonalnego mistyczne, nieśmiertelne ciało króla to prekursor czegoś, co znamy doskonale z naszej własnej rzeczywistości społecznej: osoby prawnej (s. 233). I dalej równie niedwuznacznie: Operacja konceptualnego podwojenia ciała króla pozwala na zestawienie teologiczno-politycznego równania: KRÓL W SWOIM CIELE POLITYCZNYM = KORONA = PAŃSTWO (s. 234). Konsekwencją takiego rozumienia nieśmiertelnego ciała króla jest wniosek: Jeśli zgodzimy się, że monarcha jako reprezentant dynastii wyrażającej ciagłość wspólnotowej formy państwa łączy w swojej osobie dwa ciała - indywidualne, śmiertelne ciało naturalne oraz nieśmiertelne ciało polityczne - musimy stwierdzić, że wszyscy władcy I Rzeczypospolitej po Zygmuncie Auguście byli okaleczeni i posiadali tylko jedno ciało: swoje własne ciało fizyczne. Monarchia elekcyjna I Rzeczypospolitej zaprzecza we wszystkich najważniejszych punktach doktrynie dwóch ciał króla (s. 237). Chaotycznie prowadzone wywody Habilitanta mają uzasadniać główną tezę rozprawy o nieistnieniu państwa polskiego od 1572 r. poczynając i o wynikających z tego konsekwencjach społecznych, gospodarczych, politycznych i wszelkich innych: Szlachta zabiła więc polityczne ciało króla, sprawiajac, że Rzeczpospolita stała się państwem fantomowym. Jego stopniowa dekompozycja między XVI a XVIII wiekiem to nic innego jak gnicie martwego politycznego ciała króla (s. 252). To kaskada nieporozumień, błędów, omyłek, niekompetencji. Habilitant pochopnie, a nieodpowiedzialnie, formułuje tezy, które są dlań wygodne, nie przejmując się tym, że nie mają one racjonalnego uzasadnienia i pozostają ze sobą w sprzeczności. Czy na tym koniec ignorancji Jana Sowy?

\section{Pseudonauka}

Jak się okazuje, Habilitant wypisuje bzdury nierozważnie w toku postępowania habilitacyjnego uznane za znaczący wkład w rozwój nauki. 
Zgadzamy się w całej rozciągłości z jednym z recenzentów uczestniczących w postępowaniu „chabilitacyjnym”, który stwierdził, że aby wskazać wszystkie popełnione przez „Chabilitanta” błędy należałoby napisać kolejną książkę $e^{51}$. Przywołajmy inny fragment oceny, który wyszedł spod pióra tego samego recenzenta: Nie sposób ocenić czy setki błędów rzeczowych oraz irytujacych interpretacji obecnych w pracy habilitacyjnej były jedynie następstwem strategii postępowania badawczego ${ }^{52} c z y$ też następstwem niewiedzy i nieznajomości warsztatu historycznego. Różnimy się z profesorem Andrzejem Chwalbą co do jednego: uważamy, że tak negatywna ocena walorów „historycznych” rozprawy, której celem było skorygowanie naszej wiedzy historycznej, nie może być żadną miarą podstawą do pozytywnego wniosku recenzji. Dyskwalifikuje naukowość rozprawy całkowicie!

Coś nadto? Autor wskazuje, że jego studium wspiera się na proponowanym przez C. Leforta rozumieniu nowoczesnej demokracji, które obraca się wokół trzech zaimków: "nikt”, „każdy” i „kiedykolwiek”. Żaden $z$ nich nie znajduje zastosowania ani $w$ teorii, ani $w$ praktyce demokracji szlacheckiej [s. 286-287]. „Nikt” ma oznaczać, że żadna pojedyncza osoba, ani też klasa lub grupa społeczna nie może sobie przypisać władzy (suwerenności). We właściwym sensie suwerenne pozostaje tylko samo prawo [s. 287]. I tu kolejny problem: bo to - wbrew Habilitantowi - właśnie opis demokracji szlacheckiej. Zasada in Polonia lex est rex stanowi właśnie o suwerenności prawa w państwie szlacheckim. Co do tego nie ma żadnych wątpliwości ${ }^{53}$. O tym Jan Sowa nie wie. Znowu kardynalny błąd w konstruowaniu kolejnego fundamentu habilitacji.

Jakby tego było mało, co rusz natykamy się na inne jej wady.

${ }^{51}$ Aby odnieść się do wszystkich błędnych zdań recenzent musiałby napisać książkę, A. Chwalba, Recenzja [habilitacyjna] dorobku naukowego doktora Jana Sowy (19 września 2012).

52 Strategia badawcza popełniania setek błędów? Czy to kolejna nowość wprowadzona do badań humanistycznych przez Jana Sowę?

53 Por W. Unuszczak, 'In Polonia lex est rex'. Niektóre cechy ustroju Rzeczypospolitej XVI-XVII w., [w:] Polska na tle Europy XVI-XVII wieku, Konferencja Muzeum Historii Polski, Warszawa 2007, materiały pokonferencyjne, z. 1. 
Polska nie była państwem w żadnym właściwie aspekcie uwzględnianym przez jakąkolwiek definicje państwowości [s. 40] - to oczywista nieprawda. Autor nie przytacza żadnej definicji państwowości dla potwierdzenia prawdziwości swej tezy, ale w dalszych rozważaniach już bez wahania opowiada, że Rzeczpospolita istniała jako państwo $w$ standardowym sensie tego słowa nie więcej niż 3 lata [s. 239].

Przytoczenie jakiejkolwiek definicji państwowości, uznającej państwowość Polski czasów wolnej elekcji zmusi do odrzucenia a limine twierdzenia zawartego w książce Sowy. A zatem: Art. 1 The state as a person of international law should possess the following qualifications: (a) a permanent population; (b) a defined territory; (c) government; and (d) capacity to enter into relations with the other states ${ }^{54}$. Zgodnie $\mathrm{z}$ tą definicją prawa międzynarodowego państwo szlacheckie było państwem w pełnym znaczeniu tego słowa: miało na stałe ulokowaną ludność, określone terytorium, miało swoje władze, dysponowało też (aż do ostatniej chwili swego istnienia) zdolnością wchodzenia w relacje z innymi państwami.

Co więcej, i sam Habilitant w wielu miejscach swej rozprawy habilitacyjnej nie ma wątpliwości, że państwo szlacheckie realnie istniało. Jednoznacznie eksponuje to, podsumowując dyskusję na temat brzegowych dat whistorii państwa szlacheckiego, gdy stwierdza, że można zaproponować następujaca periodyzacje jego istnienia: 1466-1795 - ramy historyczne Rzeczypospolitej Szlacheckiej [s. 306]. Teza o latach istnienia nieistniejącego państwa wprawia w zdumienie, nasilając wątpliwości co do logiki wywodów Jana Sowy.

Kolejnym założeniem habilitacji ma być teza o znaczącej wartości linii podziału Europy przez rzeki Łabę i Dunaj. Występująca w pewnych okresach granica nie stanowi żadnej prawidłowości historycznej czy psychologicznej, lecz za każdym razem jest skutkiem złożonych okoliczności, zwłaszcza relacji politycznych między państwami oraz stosunków gospodarczych panujących w danym czasie w konfrontacji z warunkami geograficznymi, a jedyna prawidłowość w powtarzalności historycznej tej granicy ma związek z naturalną właściwością wielkich rzek jako

54 Montevideo Convention on the Rights and Duties of States z 26 grudnia $1933 \mathrm{r}$. 
przeszkody terenowej. Na Łabie i Dunaju nie ciąży żadne fatum, które czyniłoby z nich stałą czy trwałą granicę dzielącą Europę. Była to zresztą granica w sumie krótkotrwała. W czasach rzymskich dzieliła Imperium od Germanii tylko za rządów cesarza Augusta. W następstwie klęski w Lesie Teutoburskim (9 r.) doszło do wycofania Rzymian na linię Renu, czego Habilitant nie zauważył. To właśnie na linii Renu i Dunaju, a nie Łaby-Dunaju przebiegała granica wschodnia i północna Cesarstwa Rzymskiego. Granica na Łabie ukonstytuowała się dopiero w czasach panowania Karola Wielkiego jako wschodnia granica jego cesarstwa. Przetrwała niewiele ponad 100 lat, dzieląc terytoria zasiedlone przez Germanów i Słowian, zasadniczo tylko w jej dolnym biegu. Środkowy i górny odcinek Łaby niczego w tym czasie nie dzielił, gdyż tereny po obu brzegach Łaby opanowane były przez plemiona słowiańskie, na których powstało najpierw państwo wielkomorawskie, a następnie czeskie. Dodajmy, że w X w. rozpoczęła się ekspansja niemieckich feudałów na Wschód, w następstwie czego także Dolna Łaba przestała pełnić funkcję rzeki granicznej. Co do roli linii Łaby-Dunaju jako granicy systemów społeczno-ekonomicznych dzielących Europę wschodnią od zachodniej w późnym średniowieczu i czasach nowożytnych, to, po pierwsze, żaden z historyków gospodarczych uznających tego rodzaju granicę nie wiąże jej z Dunajem. Wskazywana jest jedynie rzeka Łaba i to w sumie bardzo „orientacyjnie” "55. Mamy tu do czynienia z następstwem procesów zachodzących w związku z zacieśnieniem stosunków gospodarczych między różnymi regionami Europy i tworzącym się ogólnoeuropejskim rynkiem kapitalistycznym. Historycy gospodarczy bynajmniej nie widzą w tej linii podziału Europy niczego nieprawidłowego. Natomiast w wiekach XVIII i XIX z pewnością granica ta nie stanowiła Rubikonu zacofania na Wschodzie i postępu na Zachodzie. Na wschód od Łaby znajdowało się Królestwo Prus, które w XVIII w. stało się modelową monarchią absolutyzmu oświeconego, zaś w XIX w. było europejskim mocarstwem. Niewiele gorszy status miała monarchia habsburska pod rządami cesarzowej Marii Teresy i Józefa II, których państwa leżały

55 Por. W. Rusıński, Zarys historii gospodarczej Polski na tle dziejów gospodarczych powszechnych, Warszawa 1986, s. 47. 
w znacznej części na północ od Dunaju i na wschód i północ od Łaby. Doszukiwanie się w istniejącej co pewien czas granicy na Łabie i Dunaju jakiejkolwiek prawidłowości w ewolucji dziejowej Europy nie ma żadnej wartości poznawczej i wynika z niekompetencji.

Na zakończenie wskażmy - nie wyczerpując bogatej listy błędów eksponowane przez Jana Sowę zagadnienie specyfiki na tle europejskim zdominowanego przez magnatów polskiego ustroju [s. 307] oraz kwestię monarchy absolutnego: monarchia absolutna, której brak w państwie szlacheckim, miała stać się najważniejszym czynnikiem gwarantującym rozwój postępowego kapitalizmu na zachodzie Europy. Natomiast oligarchia magnacka I Rzeczypospolitej miała być czynnikiem jej zgonu. Nie widzimy sensu podejmowania polemiki z tym nieporozumieniem. Wskażmy jedynie, że w przywoływanej [s. 249 i 306] przez J. Sowę pracy M. Markiewicza zawarte zostało jednoznaczne stwierdzenie o bezzasadności przekonania o wyjątkowości polskiego ustroju w XVI-XVII wieku ${ }^{56}$. Habilitant ani słowem nie odnosi się do tych podważających jego koncepcję uwag.

\section{Plagiaryzm}

Naukowy charakter rozprawy habilitacyjnej wymaga, by autor respektował podstawowe normy regulujące uprawianie nauki. Zalicza się do nich obowiązek jednoznacznego wskazywania, co jest osiągnięciem Autora, a co ustaleniem poprzedników. Brak takiego wskazania, czyli przypisywanie sobie cudzych ustaleń, nazywane jest plagiatem. Odwołać się tu należy do standardów obowiązujących w świecie akademickim, expressis verbis wskazywanych w wiodących centrach naukowych ${ }^{57}$.

56 M. Markiewicz, Demokracja szlachecka, oligarchia magnacka - zdziejów pewnych pojęć, [w:] Między barokiem a oświeceniem. Apogeum sarmatyzmu, red. K. Stasiewicz, S. Achremczy , Olsztyn 1997, s. 40-41.

57 Plagiarism occurs when you use another's words, ideas, assertions, data, or figures and do not acknowledge that you have done so, https://integrity.mit.edu/ handbook/what-plagiarism. Zwraca się uwagę, że in some cultures, the concept of "owning" words that are arranged in a particular sequence may seem strange. Students 
Zgodnie z nimi, by uniknąć zarzutu plagiatu, należy przy wykorzystaniu cudzych ustaleń wyposażyć je przy parafrazie w:

- wskazanie w tekście, że wykorzystany jest cudzy dorobek

- precyzyjne wskazanie miejsca, skąd ideę zaczerpnięto

- wskazanie granic parafrazy

- odsyłacz pod tekstem

przy cytacie natomiast $\mathrm{w}$ :

- cudzysłów,

- jednoznaczne wskazanie miejsca wyciętych z cytatu fragmentów,

- odsyłacz pod tekstem ${ }^{58}$.

To nie do czytelnika należy rozstrzyganie, jaki charakter ma wypowiedź sformułowana w rozprawie naukowej, czy i skąd została zaczerpnięta. Brak odpowiedniej informacji oznacza przypisanie sobie cudzego ustalenia.

Respektowanie tych zasad jest ważne ze względów etycznych. Ma też znaczenie ze względów prawnych - grozi nieprzedawnialną odpowiedzialnością karną plagiatora, a także utratą uzyskanych dzięki plagiatowi korzyści (przede wszystkim stopni i awansów naukowych). Jednak nie to są powody najważniejsze. Tępienie nieuczciwości naukowej jest konieczne ze względu na szkody, jakie niesie za sobą ukrywane przejmowanie cudzych ustaleń, stwarzające złudzenie postępu. Pseudonauka to ogromne, hamujące rozwój nauki marnotrawstwo. Promuje ona $\mathrm{w}$ środowisku akademickim niekompetencję, nierzetelność, cwaniactwo i hochsztaplerkę, wyklucza zaś naukowy postęp, deprecjonując przy tym

from these cultures may have been encouraged to repeat the words of others and incorporate them into their own writing without quoting or otherwise indicating that they came from another source. Other cultures accept the practice of copying phrases or sentences into a paper without using quotation marks as long as the writer shows where they came from. These practices are not acceptable in North American academic culture. Podkreślenia godna niezwykła staranność, z jaką MIT kształtuje rzetelność wykorzystywania cudzych słów i idei, jednoznacznie, w sposób niebudzący wątpliwości wskazując już studentom (!) zasady cytowania, parafrazowania. Por też http://www.princeton.edu/pr/pub/integrity/pages/plagiarism/, http://www.ox.ac.uk/ students/academic/guidance/skills/plagiarism, dostęp 23 listopada $2016 \mathrm{r}$.

58 How to Recognize Plagiarism, https://www.indiana.edu/ istd/patterns.html, dostęp 23 listopada 2016 r. 
sumienną pracę, gdyż wymagające długotrwałego wysiłku badawczego gruntowne studia przestają się opłacać, przegrywając w konfrontacji z naukową nieuczciwością.

Przypomnijmy: Habilitant zapowiada, że nie chodzi mu o poszukiwanie nowych danych, które zrewidują obraz jakiejś epoki historycznej, ale o rekonfigurację i reinterpretację faktów, procesów i zjawisk już opisanych w historiografii [s. 50]. Czyli każdy fakt, proces i zjawisko historyczne, o jakim mowa w habilitacji, jest ustaleniem w cudzym dorobku. Habilitanta obciąża zatem obowiązek wskazywania na badaczy, których osiągnięcia wykorzystuje. W tym przypadku anonimowość staje się nadużyciem, gdyż pozbawia możliwości rozstrzygnięcia, co jest, a co nie jest dorobkiem Autora. Trudno też wówczas skonstatować, czy przejęcie cudzego ustalenia zostało dokonane poprawnie. Wbrew przekonaniu Jana Sowy nie istnieje domniemanie plagiatowej niewinności. Ciężar dowodu spoczywa na dysponującym odpowiednią aparaturą naukową wykorzystującym cudzy dorobek badaczu. Po to ją stworzono.

Trzeba też przyjąć, że wszelkie przejawy inkryminowanej postawy dyskwalifikują badacza, niezależnie od rozmiaru przejątku. I choć Jan Sowa próbuje się usprawiedliwiać niewielką procentowo skalą uprawianego przez siebie zapożyczania ${ }^{59}$, to jednak złamanie zakazu pozostaje złamaniem prawa. Z drugiej strony nie można uznać za akceptowalną postawę, w której autor chce odnieść korzyść z tego, że nie wszystkie przypadki dokonanych przezeń zapożyczeń zostały ujawnione. Nie wiadomo bowiem, ile ich należałoby wskazać dla dyskredytacji rozprawy?

Przemilczenia dotyczące źródeł ustaleń przejmowanych w przedstawionej przez Jana Sowę rozprawie habilitacyjnej mają charakter masowy. Czytając habilitację, stale odnosimy wrażenie, że znajdujemy w niej tezy, które formułowano już dawniej. I inni czytelnicy opisują takież doznanie: niekiedy trudno oprzeć się wrażeniu, że Jan Sowa proponuje coś, co właściwie już było, ale podaje to jedynie w innym „dressingu” [...] przysłowiowe przekonanie o odkryciu Ameryki przez autora ma pewien

59 J. SowA, Z takim sposobem uprawiania "polemik naukowych” godzić się nie można. Odpowiedź Wacławowi Uruszczakowi, «SDPiPP», 18/2015, s. 284. 
urok $^{60}$. Tak exempli causa wskażmy zbieżność stanowiska Jana Sowy i przedstawicieli tzw. szkoły krakowskiej. O uczonych poprzednikach w rozprawie ni słowa.

Uważamy, że ignorantia historiographiae, tak jak ignorantia iuris szkodzi i daje podstawy do twierdzenia o przejmowaniu cudzych ustaleń bez wskazania autorstwa. Czyli uzasadnia zarzut niedozwolonej zależności od dorobku poprzedników.

Podajmy - niewyczerpująco - charakterystyczne przykłady nieuczciwości naukowej Habilitanta ${ }^{61}$.

J. Sowa, s. 238 przyp. $44^{\star}$

Dopiero w 1764 roku sejm postanowił postawić kropkę nad „i”, orzekając, że uchwały sejmowe z czasów bezkrólewia, aby obowiązywać, nie potrzebują sankcji nowego króla.

Więcej na ten temat por S. Płaza, Wielkie bezkrólewia, Kraków 1988, s. $32-33$
S. Płaza, Wielkie bezkrólewia, s. 33

Usunie je dopiero sejm koronacyjny Stanisława Augusta Poniatowskiego (1764) postanawiając, że uchwały sejmowe z czasów bezkrólewia, aby obowiązywać, nie potrzebują sankcji nowego króla.

W przywołanym fragmencie Jan Sowa p r z e p is a $\nmid$ tekst swojego poprzednika, ale nie oznaczył tego za pomocą cudzysłowu, dokonał też parafrazy, nie dopełniając obowiązku informacji o zakresie przejęcia.

$\mathrm{W}$ innym miejscu przepisuje dosłownie, ale cytatem nie oznacza przejętego tekstu:

60 E. Flieger, Peryferyjne zmagania z forma Jana Sowy, «Sensus Historiae», $11.2 / 2013$, s. 215. Trudno tę uwagę kwestionować, bo nawet najbardziej zaangażowany czytelnik ma trudności ze stwierdzeniem, co nowego wnosi do nauki rozprawa Jana Sowy.

${ }_{61}$ Wcześniej wskazane, por W. URUszCZAK, Z takim sposobem uprawiania nauki godzić się nie można. Naruszanie cudzego autorstwa w pracach historycznoprawnych i historycznych, «SDPiPP» 18/2015, s. 233 i n. 
J. Sowa, s. 112 przyp. 2

trzy cechy: duża rola gospodarki naturalnej, ograniczenie prawa chłopa do ziemi do zwykłego użytkowania oraz poddaństwo chłopów
J. Topolski, Narodziny kapitalizmu..., s. 15 trzy takie cechy: duża [...] rola gospodarki naturalnej, ograniczenie prawa chłopa do ziemi do zwykłego użytkowania [...] oraz poddaństwo chłopów

Kolejny fragment habilitacji zawiera i cytat bez odesłania, i parafrazę bez wskazania źródła:

J. Sowa, s. 245-246

Gwarantowały one szlachcie zachowanie wszystkich dotychczasowych przywilejów, zobowiązywały monarchę do przestrzegania istniejących praw Rzeczypospolitej oraz wszystkich nowych, które uchwaliłby Sejm, nakazywały królowi zwoływanie Sejmu co dwa lata na okres 6 tygodni, ustanawiały radę szesnastu senatorów, która miała cały czas towarzyszyć królowi na dworze, zakazywały monarsze podejmowania istotnych decyzji politycznych bez zgody tychże senatorów, oddawały politykę wewnętrzną i zagraniczną pod kontrolę sejmu,
T. Cegielski, K. Zielińska,

Historia Dzieje nowożytne. Podręcznik dla szkót średnich klasy II liceum ogólnokształcącego, Warszawa 1991, s. 61-62.

gwarantowały szlachcie zachowanie wszystkich nadanych dotychczas przywilejów. Określały zasady ustroju obu państw Rzeczypospolitej oraz miejsce w nim i uprawnienia władcy. Król miał przestrzegać wolnej elekcji, zwoływać regularnie co dwa lata sejm, poddać politykę wewnętrzną i zagraniczną kontroli sejmu oraz nie podejmować istotnych decyzji politycznych bez rady senatorów stale rezydujących na dworze.

Zależność tekstu rozprawy habilitacyjne od podręcznika licealnego objawia się nie tylko w przejęciu treści z podręcznika, ale w znaczącej 
mierze w przejęciu podręcznikowych sformułowań. A to znowu nie jedyny taki przypadek:

J. Sowa, s. 308

Za panowania Jana Kazimierza na 20 sejmów zerwano „tylko” 7 , za Michała Korybuta Wiśniowieckiego i Jana III Sobieskiego na 18 sejmów zerwano 10 ,
T. Cegielski, K. Zielińska, Historia Dzieje nowożytne. Podręcznik dla szkół średnich..., s.166

Za panowania Jana Kazimierza na dwadzieścia sejmów zostało zerwanych siedem. Za następców, Michała Korybuta Wiśniowieckiego i Jana III Sobieskiego [...] na osiemnaście sejmów zerwano aż dziesięćc2

Żenujące, że habilitacja musi wspierać się ukrywaniem zapożyczeń $z$ licealnego podręcznika!

Tezę o sejmie szlacheckim, który stał się nie tyle miejscem politycznej dyskusji między monarchą a przedstawicielami trzech stanów średniowiecznego społeczeństwa, co instrumentem $w$ rękach szlachty, stużacym do zabezpieczania jej klasowych interesów (s. 116) przedstawia Habilitant jako własną, nie wspominając chociażby, że posługiwano się nią już dawno: Szlachecka izba poselska stała się główną trybuną, na której wysuwane były żadania i podejmowane uchwały majace dać przewage szlachcie i zagwarantować jej klasowe interesy ${ }^{63}$.

Autor ukrywa źródło swej wiedzy, np. przez fałszowanie odwołania do aktów prawnych wprowadzających wobec poddanych szlacheckich ucisk i wyzysk większy niż panujacy kiedykolwiek wcześniej (s. 128). Wymienia kolejne decyzje, wskazuje na ich treść (s. 127-128), a w najbliżej usytuowanym przypisie przywołuje nazwiska autorów (Małowist, Blum, Pach) i stronice w ich dziełach. Jednak ponad wszelką wątpliwość nie te publikacje dały podstawę do wypowiedzi Jana Sowy. Sam kwerendy

62 Nie uznajemy za twórczy wkład Habilitanta zmiany sposobu zapisywana liczebników.

63 Historia Polski PAN, I: do roku 1764, 2: do połowy XV w., red. H. Łow MIAŃski, Warszawa 1958 s. 173. 
źródłowej i analizy tekstów nie przeprowadzał. Może po prostu się wstydzi, że korzystał z Wikipedii ${ }^{64}$ ? Częściej jednak odwołań nie stosuje żadnych. Dla przykładu porównujemy ustalenie Jana Sowy z zawartością Wikipedii:

J. Sowa, s. 116

[Sejm] stał się nie tyle miejscem politycznej dyskusji między monarchą a przedstawicielami trzech stanów [...], co instrumentem w rękach szlachty, służącym do zabezpieczenia jej klasowych interesów. Znalazło to pełne odzwierciedlenie w konstytucji „Nihil novi sine commun e ${ }^{65}$ consensu" uchwalonej w 1505 r., która zakazywała królowi stanowienia nowych praw bez zgody szlacheckiego sejmu.
Wikipedia sub v. Nihil novi

Pełna formuła łacińska brzmiała nihil novi sine com muni consensu (nic nowego bez powszechnej zgody, co należy rozumieć jako: nie można uchwalić nowego prawa, na które nie zgodzi się Sejm reprezentujący powszechny interes szlachty). Zakazywała ona królowi wydawania ustaw bez uzyskania zgody szlachty

Autor charakteryzuje znaczenie wpływów tradycji upadłego imperium i prawa rzymskiego, powtarzając archaiczny pogląd („teoria

64 Tekst Jana Sowy sprawia wrażenie parafrazy zawartości Wikipedii, ale Habilitant nie wskazuje jakichkolwiek źródeł. Zbieżność treściowa obu tych tekstów jest niewątpliwa, choć zapewne Jan Sowa korzystał także z innego jeszcze źródła informującego o aktach z 1532 i 1543 r. w sprawach chłopskich. O obu mowa jest w dawniejszym piśmiennictwie, np. Teksty źródłowe do nauki historii w szkole. Nr 18 Polska wieś folwarczno-pańszczyźniana w XVI-XVIII wieku, opr. J. BARTYś i J. GoldBerG, Warszawa 1960, s. 6, 7, 11. Gotowość do korzystania z Wikipedii jest równie wysoka, jak niechęć do powoływania się na nią, por. kłopoty Zygmunta Baumana w związku z przejmowaniem w pracy Czy bogactwo niewielu przynosi korzyść nam wszystkim? dorobku Wikipedii, bez wskazania cudzego autorstwa; por Zygmunt Bauman przepisuje $z$ Wikipedii, albo wielka nauka i małe machlojki, http://kompromitacje.blogspot. com/2014/04/bauman-przepisuje-z-wikipedii.html, dostęp 24 listopada 2016 r., lub https://pl.wikipedia.org/wiki/Zygmunt_Bauman\#cite_note-20, dostęp 24 listopada $2016 \mathrm{r}$.

65 Ta błędna wersja znajduje się w angielskojęzycznej wersji hasła, tam też o usunięciu miast z sejmu. 
katastrofy") i dość niezręcznie sugerując, że Corpus Iuris Civilis zostało wydane na polecenie Justyniana [s. 86-90], bez przywołania źródła tej niepoprawnej informacji.

Habilitant ściąga bezwstydnie, acz niestarannie. Oto kolejny, żenujący przykład udawania samodzielności przez „naukowca” z Uniwersytetu Jagiellońskiego:

J. Sowa, s. 314.

Amerykańska antropolożka Sydel F. Silverman zdefiniowała tę relację jako „względnie trwały stosunek osób o nierównym statusie, [w def. Silverman nie ma ani słowa o względnej trwałości, są natomiast nierówne możliwości - uwaga JM i WU]

który nakłada na partnerów różne wzajemne zobowiązania. Ich minimum to $z$ jednej strony ochrona i łaska, a z drugiej - lojalność. Stosunek ten wymaga kontraktu osobistego, zawartego twarzą w twarz, i jest ciągły" ${ }^{\text {"47 }}$

${ }^{47} \mathrm{~S}$. Silverman, Patronage and Community-Nation Relationships in Central Italy, „Ethnology” IV (1965), s. 176.
A. Mączak, Klientela..., Warszawa 2000, s. 10

Do takich należy definicja zaproponowana przez historyka niemieckiego, Wolfganga Reinharda. Wedle niej stosunek patron-klient to „względnie trwały stosunek osób nierównych sobie, [...]". Natomiast amerykański antropolog Sydel F. Silverman w swej definicji akcentuje pewne dodatkowe elementy, widząc ów układ jako „nieformalny stosunek umowny między osobami o nierównym statusie i możliwościach, który nakłada różnego rodzaju wzajemne zobowiązania na partnerów. Jako minimum $\mathrm{z}$ jednej strony należy się ${ }^{66}$ ochrona i łaska, $z$ drugiej zaś lojalność. Stosunek ten oparty jest na kontakcie osobistym, twarzą w twarz, i jest ciągły"

Jan Sowa zagapił się i nie zauważył, że początek definicji przepisuje z innego akapitu pracy A. Mączaka (przejmując fragment definicji zaproponowanej przez Reinharda), a resztę kopiuje wprowadzając zmiany

${ }^{66}$ Należy się to tłumaczenie what is owed. Jan Sowa, parafrazując przekład prof. Mączaka, nie wie, że wyrzuca istotny fragment definicji. 
redakcyjne z innego miejsca $\mathrm{z}$ innej przełożonej przez A. Mączaka i przedstawionej w kolejnym akapicie definicji. Popełnia przy tym błąd. $\mathrm{W}$ oryginale czytamy: The relationship is on a personal face-to-face basis. Prof. Mączak przekłada to poprawnie Stosunek ten oparty jest na kontakcie osobistym. Sowa „kontakt” zamienia na „kontrakt”. Jedna literka, a sens inny. I jaki wstyd! ${ }^{67}$

Dodajmy jeszcze, że A. Mączak nie zauważył, co powtórzył ściągający z niego Habilitant, że Silverman nie twierdzi, że nakładane są różnego rodzaju zobowiązania, ale że każda ze stron jest obciążona powinnością o odmiennym charakterze: imposes reciprocal obligations of a differenet kind on each of the parties. To kolejne wskazanie na ukrywaną przez J. Sowę zależność jego tekstu od pracy A. Mączaka.

Nie budzi wątpliwości zła wola Habilitanta, który stara się tak manipulować tekstem i odsyłaczami, by sprawiać wrażenie, że sam sięga do obcojęzycznego tekstu i dokonuje przekładu, i że cudze myśli są jego własnym dziełem. Gdy zajmuje się „przymusem powtarzania” [s. 369-370], przywołuje przykład z Lacana wykorzystujący Skradziony list Poego. Informuje też w nawiasie, że B. Fink omawia rozumowanie Lacana na przykładzie rzutów moneta [s. 369]. Dalej jednak, już przejmując wywody B. Finka, czyni to w sposób jednoznacznie sugerujący własne autorstwo: Oznaczmy jako..., Zapiszmy następnie..., Zakodujmy wreszcie nasz szereg... możemy nazwać je regułami... i w końcu Oczywiście, jako [...] możemy zakodować dowolne konfiguracje [...] Czy też, jak ujmuje to Fink, „możliwości i niemożliwości, które się pojawiaja, można traktować jako pochodna sposobu, w jaki zorganizowana jest symboliczna matryca [podkreślenie moje - J.S.]". Odsyłacz wskazuje miejsce pochodzenia cytatu, ale w żadnej mierze nie pozwala nawet na przypuszczenie, że nie tylko fragment w cudzysłowie, ale cała wypowiedź Sowy jest kopią wywodu Finka.

Wszelkie granice przekroczono w nieoznaczonym cudzysłowem, sparafrazowanym cytacie:

67 Co zabawne: A. Mączak powołuje w przypisie cały czterotomowy rocznik 1965, choć poprawny, pełny przypis wymaga wskazania numeru zeszytu: Silverman, S.F. (1965). Patronage and Community-Nation Relationships in Central Italy. Ethnology, 4 (2), s. 172-189. Ten sam błąd powtarza Sowa. 
J. Sowa, s. 92-93

Tak na przykład w Anglii w manorze Forncett dochody z czynszu za jeden akr ziemi kształtowały się następująco: w 1378 roku - 10,69 d., w 1410 $-9,11$, w 1140 - 8,02, a w $1460-2,29$. Oznacza to spadek około $80 \%$ na przestrzeni 80 lat.

Podobnie było wszędzie: w seniorii Neufbrourg w Normandii tylko w samych latach 1436-1437 czynsze spadły o $60 \%$.

W Sologne, w centralnej Francji, w połowie $\mathrm{XV}$ wieku dochód pana spadł z 20 do 2 liwrów.

W przypisach powołanie s. 65 i 64 pracy J. Topolskiego
J. Topolski, Narodziny kapitalizmu w Europie XVI-XVII wieku, Poznań 2003

[s.65] W manorze Forncett, zacytujemy przykładowo za G. Duby, w 1376-1378 r. akr ziemi oddany był w czynsz za 10,69 d., w 1405 1410 za 9,11, w $1431-1440$ za 8,02 , a w 1451-1460 za $6,2 \underline{6 \mathrm{~d}}$., czyli spadek w ciągu ok. 80 lat wynosił prawie $40 \%$. [s. 64] W seniorii Neufbourg w Normandii tylko w latach 1436-1437 czynsze spadły o ok. $60 \%$. $\mathrm{W}$ jednej z seniorii w Sologne dochód pana w połowie XV w. spadł z 20 na 2 liwry ${ }^{105}$. ${ }^{105} \mathrm{G}$. Duby, L'économie rurale, s. 595

Habilitant fałszuje dane statystyczne zaczerpnięte z przywołanej pracy Jerzego Topolskiego, zmieniając lata, z których pochodzą dane, parafrazując: spadek $w$ ciagu ok. 80 lat wynosit prawie 40\%. na spadek około $80 \%$ na przestrzeni 80 lat. Fałszerstwem jest wskazanie: spadty o 60\% zamiast spadty o ok. 60\%, czy nieuprawnione stwierdzenie Podobnie było wszędzie ${ }^{68}$. Przypisywanie autorowi, z którego dorobku się korzysta, wypowiedzi, których ten nie sformułował, jest absolutnie niedopuszczalne. Jeśli Topolski stwierdza, że akr ziemi był oddany w czynsz, to jest to informacja o planowanych przychodach. Na jej podstawie nie wolno twierdzić, jak czyni to Sowa, że dochód taki był uzyskiwany. Nawet parafraza ma swoje granice. Zwrot: W jednej

68 Nieuczciwe tym bardziej, że sprzeczne z jednoznaczną wypowiedzią J. ToPOLSKIEGO, W stosunku do całych obszarów Europy nie zauważono oznak regresji gospodarczej (s. 40). 
$z$ seniorii $w$ Sologne nie jest - jak chce Sowa - równoważny: W Solgne ${ }^{69}$. Obniżenie przez Habilitanta wysokości czynszu z 6,26 na 2,29 tylko po to by uzyskać znaczniejszy spadek dochodu: o $80 \%$ zamiast, jak u Topolskiego, o 40\%, usprawiedliwić się nie da niczym. Jedno tylko przywołanie, a ile karygodnych nadużyć Habilitanta! Tak uprawia „naukę" tylko pseudonaukowiec.

To nie przypadek jednostkowy. Habilitant chętnie posługuje się cudzym tekstem, przerabiając go dla własnych potrzeb:

J. Sowa, s. 129 przyp. 36

jak zauważa Anna Sosnowska, sposób dzisiejszego uzasadniania pańszczyzny np. przez Andrzeja Wyczańskiego przypomina argumenty wysuwane w obronie systemu plantacyjno-niewolniczego na południu Stanów Zjednoczonych. Por A. Sosnowska, Zrozumieć zacofanie
A. Sosnowska, Zrozumieć zacofanie..., s. 274 przyp. 16

Uderzające jest podobieństwo spojrzenia Wyczańskiego na folwark i pańszczyznę do uzasadniania istnienia systemu plantacyjno-niewolniczego na południu USA

Niby podobne, ale nie to samo. A. Sosnowska charakteryzuje stanowisko Wyczańskiego, nie dając podstaw do wskazania, że przywołuje tego autora li tylko przykładowo, spośród grupy innych uczonych, co bezpodstawnie sugeruje wtrącony przez Jana Sowę skrót: „np.”. Dostrzegamy też zdecydowaną różnicę między uzasadnieniem istnienia, czyli ,racjonalizacją' u A. Sosnowskiej, a obroną, czyli ,wartościowaniem’ w monografii habilitacyjnej. A to nie przypadek, gdyż Jan Sowa potrzebuje argumentów za przyjmowanym przez siebie, a dawno odrzuconym $\mathrm{w}$ literaturze zrównaniem poddaństwa $\mathrm{z}$ niewolnictwem.

Jan Sowa krytykuje wypowiedź J. Topolskiego, że miasta pozostawały w społeczeństwach feudalnych ,ciałami obcymi” [s. 97], ale nie informuje czytelnika, że krytykowany zastrzegł: dla uniknięcia nieporozumień, że

69 Wyliczenie seniorii Sologne można znaleźć w H. Klimrath, Histoire du droit. Etudes sur les coutumes, «Revue des Revues de droit», Bruxelles 1839, s. 22. 
takim postawieniem sprawy nie chcielibyśmy sprawiać wrażenia niedoceniania spraw miejskich $w$ feudalizmie. W innym miejscu stwierdza, że Jerzy Topolski jest zdania, że nawet $w$ Holandii polskie zboże się nie liczyło, jeśli chodzi o bezpośredniq konsumpcję. [s. 138], gdy we wskazanym miejscu czytamy co innego: Nawet dla Amsterdamu dostawy zbóż $z$ regionu bałtyckiego, mimo że stałe miały charakter marginalny. Amsterdam to nie cała Holandia, a region bałtycki to jednak nie Polska.

A oto ciąg dalszy nadużyć.

Na s. 94 znajdujemy syntetyczny schemat dobrze ujmujący mechanizm kryzysu: „Rys. 3. Mechanizm kryzysu późnego średniowiecza. Źródło: Topolski, Narodziny kapitalizmu..., dz. cyt., s. 39.” Czytelnik mógłby sądzić, że to Habilitant opracował schemat na podstawie materiału zgromadzonego w przywołanej pracy. Nic podobnego - mamy do czynienia ze skopiowaniem schematu sporządzonego przez J. Topolskiego, a jedynym wkładem Jana Sowy jest tytuł: Mechanizm kryzysu późnego średniowiecza. A to już jest kolejne nadużycie, bo poznański historyk w swoim schemacie zestawia poglądy zwolenników koncepcji kryzysu $w$ literaturze zachodnioeuropejskiej (s. 38), wyjaśniając dalej (s. 40), że spośród 13 zestawionych elementów kryzysu w historiografii nie zakwestionowano jedynie 3. Habilitant tego nie zauważył!

Nawet wtedy, gdy decyduje się na wskazanie źródła przejmowanych ustaleń, czyni to w taki sposób, by utrudnić (czy uniemożliwić) dotarcie do nich czytelnikowi. Cóż bowiem warte odesłanie do niemal 50 stron, na których trzeba szukać jednej „sugestii”70:

70 A co powiedzieć, gdy natrafiamy na odesłanie do całej książki, np. ukrywa się trwanie zacofania i unowocześnienie nędzy, aby użyć terminu Ivana Illicha [s. 32]. Odsyłanie do książek czy ich dużych partii (por. m.in. s. 62, przyp. 29, czy s. 64, przyp. 33, czy też powołania pozorne przez wskazania całej książki A. WyCzAŃsKıEgo, Polska w Europie XVI stulecia, Warszawa 1973: Sowa, s. 164, przyp. 107, s. 167, przyp. 112, s. 168, przyp. 113) jest nie tylko dowodem niestaranności. 
J. Sowa, s. 26

Kresy można nazwać „polskimi” tylko wtedy, gdy zgodnie z sugestią Normana Daviesa „polskość” rozumiemy analogicznie do „brytyjskości” jako rodzaj nadrzędnej, wieloetnicznej i wielokulturowej tożsamości społeczno-politycznej ${ }^{25}$

${ }^{25}$ Por N. Davies, Boże igrzysko. Historia Polski, Rozdział 2, Polska. Kraj, tłum. E. Tabakowska, Kraków 1990, s. 51-97.
N. Davies, Boże igrzysko. Historia Polski, Kraków 1990, s. 51-97.

Na wskazanych stronach N. Davies pisze $\mathrm{m}$. in. o położeniu geopolitycznym Polski, o jej terytorium, o Saisonstaat, o zmianach terytorialnych, podziale na prowincje i ich charakterystyce, o Prusach, Ukrainie i Białorusi, o problemach etnicznych, o systemie rzek, klimacie i opadach, faunie, archeologicznej przeszłości, ojczyźnie Słowian, wędrówce ludów, gęstości zaludnienia, Celtach, Bałtach, Wiślanach, dziejach pierwotnego rolnictwa w Polsce, o Lustracjach, związku z Litwą, o tym, że przodkowie wszystkich $z$ nas byli mieszańcami i imigrantami i wielu innych rzeczach...

Na s. 62 czytamy o przymiotnikach: polski, brytyjski, radziecki, niemiecki. Zapewne coś przeoczyliśmy.

\section{GDZIE KOŃCZY SIĘ NAUKA?}

Habilitant padł ofiarą nierzetelnie naszym zdaniem przeprowadzonego postępowania habilitacyjnego. Członkowie Komisji habilitacyjnej wyrządzili Janowi Sowie krzywdę ogromną. To był czas, by młodemu, chcącemu podjąć karierę akademicką człowiekowi wskazać wymagania, jakie stawia się pracy naukowej, pouczyć o konieczności sumiennego zapoznawania się materiałem, który ma być przedmiotem naukowej analizy, eksponować konieczność przestrzegania wymogów prawa i etyki zawodowej. Wsparli natomiast błędne przekonanie o naukowym 
charakterze przygotowanej przez Habilitanta rozprawy, nadając pseudonauce rangę osiągnięcia naukowego ${ }^{71}$.

Zagadnienie demarkacji nauki to problem, z którym - jak dotąd nie udało się ku zadowoleniu wszystkich zainteresowanych uporać. Nie zamierzamy wkraczać w toczone filozoficzne spory ${ }^{72}$ i odwołamy się do prostszego postępowania: do podjętych już prób wyróżnienia cech, które charakteryzują pseudonaukę i pseudonaukowców.

Martin Gardner przed ponad półwieczem zestawił różnorodne koncepcje, niebudzące wątpliwości co do tego, że są produktem żądnych zysku cwaniaków lub wytworem umysłów maniaków opętanych wizją zbawienia świata lub ludzkości ${ }^{73}$. Wskazał cechy wyróżniające autorów owych wypowiedzi: Tendencje paranoidalne „klasycznego” pseudouczonego przejawiają się najczęściej w następujących [...] właściwościach (Gardner, Pseudonauka, s. 13):

- Mania wielkości autora, uważającego, że jako jedyny zna prawdę, odnosi się pogardliwie do uczonych, zarzucając im w niewybrednych słowach konserwatyzm lub wręcz nieuctwo. Tak postępuje Jan Sowa, skupiając się w swej polemice na osobach krytykujących jego dzieło. Oto zestawienie w kolejności alfabetycznej inwektyw pod naszym adresem: akademicki terroryzm, bezczelność $i$ zadufanie w sobie, denuncjacja, kpina z zasad akademickiej debaty, manipulacja, megalomania graniczaca $z$ obłędem, metodologiczne getto, nadużycie intelektualne (czy etyczne), natarczywe inwigilacje akademickich trolli, niedorzeczność, nierzetelność, nieuczciwe metody, nieuczciwość, nikczemność, obskurantyzm, osobista wendetta, personalna napastliwość oraz intelektualna nierzetelność, podłość, polityczne buldogi, sarmackie pieniactwo, stronnicze interpretowanie i manipulowanie, szaleństwo, wyjątkowo nieuczciwa manipulacja, zastraszanie pracowników nauki, zerowe kompetencje.

${ }^{71}$ Uważamy, że jedyną wartością książki jest możliwość intensywnego wykorzystywania jej na seminariach metodologicznych, gdy podejmowane są problemy błędów w pracy naukowej.

72 Por. np. L. NowAK, Metodologiczne kryterium demarkacji i problem statusu teologii, «Nauka» 3/2004, s. 121-136.

73 M. Gardner, Pseudonauka i pseudouczeni, op. cit., s. 169. 
- Ignorancja objawiająca się zarówno w nieznajomości dobrze ustalonych faktów, jak również w bezpodstawnym zaprzeczaniu a priori wszystkiemu, co nie zgadza się z poglądami autora - te cechy wskazywaliśmy wyżej, omawiając Fantomowe ciało króla.

- Ich książki zwodzą czytelnika doskonałym naśladownictwem prawdziwych, dobrze napisanych i poczytnych prac (Gardner, Pseudonauka, s. 10)

- Krytyczne wypowiedzi o pseudonauce to: objawy istnienia nikczemnego spisku. Nigdy nie przyjdzie mu do głowy, że sprzeciw jest wynikiem błędów jego pracy. Natomiast jest przekonany o tym, że opozycja wypływa ze ślepego uprzedzenia ludzi należacych do ustalonej hierarchii wysoko postawionych kapłanów wiedzy, obawiających się obalenia ich ortodoksyjnej nauki. (Gardner, Pseudonauka, s. 13) - a Jan Sowa pisze właśnie tak: Autor z powodów, których Czytelnikowi lub Czytelniczce swojego tekstu nie ujawnia, postanowit zaszkodzić mnie i mojej książce, a ponieważ uważa mnie za przejaw największego $z \nmid a^{74}$.

- Maniak ma często skłonność do zawiłego żargonu, używając raz po raz zwrotów przez siebie wymyślonych. (Gardner, Pseudonauka, s. 14).

Celem naszego wystąpienia jest obrona zasad myślenia i intelektualnej uczciwości, które sa (lub powinny być) jednakowe we wszystkich dziedzinach wied $z y^{75}$. Określenie bzdury mianem bzdury nie jest nadużyciem, lecz ma służyć zachęceniu do przeprowadzenia analizy intelektualnej nieuczciwości (lub rażacej niekompetencji), służyć temu, by usunąćaure naukowej głębi, która powoduje, że zastraszeni studenci (i profesorowie) boją się ja przeprowadzic ${ }^{76}$. Uważamy, że wprowadzanie ludzi w błąd za pomoca bredni naukowych nie jest zabawne (Gardner, Pseudonauka, s. 8), a przyznawanie naukowych awansów pseudonaukowcom jest przejawem głębokiego kryzysu w polskiej nauce.

74 J. SowA, Nota ..., s. 299.

75 A. Sokal, J. Bricmont, op. cit., s. 21.

76 A. SOKAL, J. BRICMONT, op. cit., s. 21. To, co uważa się za głębokie, często nie różni się szczególnie od tego, co jest po prostu niejasne, D.R. Olson, Pojęciowe i poznawcze implikacje pisania i czytania, Warszawa 2010, s. 28. 
Uważamy z całym przekonaniem, że rozprawa habilitacyjna Jana Sowy stanowi równie naukowe studium, jak to, które legło u podstaw Legendy o Cesarzu Kennedym.

O SYMULOWANEJ NAUCE, CZYLI O NIEKOMPETENTNEJ, NIEUDOLNEJ

I NIEUDANEJ REKONCEPTUALIZACJI SPOŁECZNEJ, KULTUROWEJ, GOSPODARCZEJ I POLITYCZNEJ HISTORII I RZECZYPOSPOLITEJ, NIERZETELNYM POSTĘPOWANIU HABILITACYJNYM I GROŹNYM POMRUKU METODOLOGICZNYM À LA OTWOCK

\section{Streszczenie}

W artykule zawarto ocenę książki Jana Sowy pt. „Fantomowe ciało króla. Peryferyjne zmagania z nowoczesną formą" (TAiWPN UNIVERSITAS, Kraków 2011, ss. 572). Książka ta traktowana jest przez niektóre środowiska naukowe jako odkrycie „nowego paradygmatu badań w naukach historycznych". Autorzy artykułu, będący historykami państwa i prawa polskiego, kwestionują wartość naukową tej pracy, kwalifikując ją jako przykład pseudonauki i naukowego pozoranctwa. Opisując stosunki gospodarcze, społeczne i polityczne w I Rzeczypospolitej (1572 - 1795) J. Sowa dopuszcza się rażących uchybień metodologicznych. W szczególności niezwykle często ignoruje fakty albo interpretuje je według z góry przyjętych założeń. Podjęta przez niego „rekonceptualizacja” odnosi się do wiedzy historycznej na poziomie podręczników licealnych, bez jakiejkolwiek wiarygodnej analizy źródłowej. Materiał historyczny wykorzystywany został wybiórczo z notoryczną ignorancją rzeczywistości. Za pseudonaukę należy uznać zwłaszcza rozważania poświęcone psychoanalizie polskiej przeszłości oparte na metodologii Jacque'a Lacana, w obliczu poddania jej w literaturze gruntownej krytyce w zakresie zastosowań matematyki (A. Sokal, J. Bricot). Fundamentalna teza J. Sowy o nieistnieniu państwa polskiego po 1572 r. (Rzeczpospolita Obojga Narodów jako „fantomowe ciało króla”) jawi się jako nonsens, wynikający z niezrozumienia teorii Ernsta Kantorowicza o dwóch ciałach króla: fizycznym i politycznym i fałszywej jej aplikacji do polskich realiów historycznych. Poprzedzająca I Rzeczpospolitą monarchia 
Jagiellonów nigdy nie była ciałem politycznym króla („jednoosobową korporacją"), lecz ciałem politycznym zbiorowym o uznanej osobowości prawnej (Corpus Regni, Corona Regni Poloniae). Nie ma wątpliwości, że Rzeczpospolita jako państwo istniała także po wygaśnięciu dynastii Jagiellonów, aż do 1795 r., a wolna elekcja czy liberum veto nie pozbawiały tego państwa realnego bytu prawnego. Teza o nieistnieniu I Rzeczypospolitej jako państwa nie opiera się na żadnej teorii państwa, a więc tym bardziej nie ma wartości naukowej. W pracy występują błędy rzeczowe, jak teza o trwałości granicy na Łabie i Dunaju. Aprioryczna założenie o wyższości monarchii absolutnej nad ustrojem monarchii mieszanej, jaką była I Rzeczpospolita, rozmija się tezami najnowszej historiografii. Wartość pracy jako samodzielnego dzieła naukowego podważają liczne zapożyczenia z prac innych autorów bez poszanowania autorstwa.

On Simulated Scholarship: An Incompetent, Flawed and Failed Reconceptualisation of the Social, Cultural, Economic, and Political History of the First Polish Republic:

A Casually Conducted Procedure for the Habilitation Degree, and a Menacing Methodological Backwash

\section{Summary}

This article is a review of Jan Sowa's book Fantomowe ciało króla. Peryferyjne zmagania $z$ nowoczesna forma (The Phantom Body of the King: Peripheral Struggles with a Modern Form, TAiWPN, Kraków: UNIVERSITAS, 2011, pp. 572). Some academic circles treat this book as the discovery of "a new paradigm for research in the disciplines of history." The reviewers, historians of the Polish State and its law, challenge the book's scholarship and qualify it as an example of pseudo-scholarship and sham academia.

In his description of economic, social, and political relations in the First Polish Republic in 1572-1795 J. Sowa commits a series of flagrant methodological errors. In particular, very often he ignores the facts or interprets them on the basis of presuppositions. The "reconceptualisation" he embarks on is conducted on the basis of a knowledge of history 
at the level presented in grammar-school textbooks, with no hint of the necessary analysis of the sources. His use of the historical material is selective and notoriously ignorant of the realities. The aspect of his book which qualifies especially for the label of pseudo-scholarship is his psychoanalysis of Polish history based on the Lacanian methodology, which has been pulled to pieces by critics like A. Sokal and J. Bricot for the use it makes of mathematics. Sowa's fundamental hypothesis that there was no Polish State after 1572 - that the Commonwealth of Poland and Lithuania was "a phantom body of the king" - is an absurdity due to its author's failure to understand Ernst Kantorowicz's theory of the king's two bodies, physical and political, and hence its misapplication to the realities of Polish history. The Jagiellonian kingdom which preceded the First Republic was never the body politic of its monarch, but a collective body politic with a recognised, enfranchised legal status as the Corpus Regni or Corona Regni Poloniae. The Polish-Lithuanian Republic most definitely continued to exist as a state after the extinction of the House of Jagiellon in 1572, right up to 1795; and neither the right of all who were enfranchised to take part in the election of its monarch nor the practice of liberum veto deprived that state of its statehood as a legal entity. Sowa's claim that the First Polish Republic was not a state is not founded on any theory of the state, which makes it even more unwarranted as scholarship. The book is also wrong on objective facts, such as the alleged permanence of the borders along the Elbe and Danube. The aprioristic assumption of the superiority of absolute monarchy over the First Republic's mixed monarchy is at odds with the opinions expressed in the recent historiography. The scholarship of Sowa's book is further undermined by his numerous borrowings from the work of others without the requisite acknowledgement.

Słowa Kluczowe: historia Polski XVI-XVIII w.; I Rzeczpospolita ustrój; metodologia historii; historia kultury; krytyka naukowa w historiografii; paradygmat badań humanistycznych; habilitacja; postępowanie habilitacyjne; pseudonauka; pseudopsychoanaliza w historiografii; plagiatorstwo. 
Keywords: history of Poland $\left(16^{\text {th }}-18^{\text {th }} \mathrm{c}\right.$.); the political and constitutional system of the First Republic of Poland; methodology of history; history of culture; academic criticism in historiography; the humanities research paradigm; the Polish post-doctoral habilitation degree; habilitation proceedings; pseudo-scholarship; pseudo-psychoanalysis in historiography; plagiarism.

\section{Literatura:}

Adamkiewicz S., Banialuki Pana Sowy, http://kuznia.art.pl/recenzje/874-fantomowe-cialo-krola-jan-sowa.html

BıAŁeK F., Realne, czyli polskość, http://nowe-peryferie.pl/index.php/2012/11/ realne-czyli-polskosc/

Bohuszewicz P., Hermeneutyki sarmatyzmu, [w:] Tradycje szlacheckie we wspótczesnej kulturze polskiej. Przybliżenia i perspektywy badawcze, red. M. Lutomierski, Toruń 2014, s. 105-130

BRODACKI J., Uczony kult cargo albo nieustraszeni pogromcy wampirów. Czytanie Jana Sowy Fantomowe ciało króla, http://www.taraka.pl/uczony_kult_ cargo_albo (dostęp 1 kwietnia 2015 r.)

Cegielski T., K. Zielińska K., Historia 2. Dzieje nowożytne. Podręcznik dla szkół średnich klasy II liceum ogólnokształcącego, Warszawa 1991

DAvies N., Boże igrzysko. Historia Polski, Kraków 1990

DąBRowski J., Korona Królestwa PoLskiego w XIV w., Wrocław-Kraków 1956,

DzIĘGIELEWSKI J., Sejmy elekcyjne, elektorzy, elekcje 1573-1764, Pułtusk 2003.

Flieger E., Peryferyjne zmagania $z$ forma Jana Sowy, «Sensus Historiae» 11.2/2013, s. 208-215;

Frost I. R., Pełen uniżoności brak szacunku: problem władzy królewskiej w Rzeczypospolitej Obojga Narodów za panowania Wazów, 1587-1668, Warszawa 2010, s. 187-210.

Frost I. R., The Polish-Lithuanian Monarchy in European Context, c. 1500-1795, red. R. BUTTERWICK, 2001

Gabiś T., Dwaj Panowie S. o pożytkach z kolonizacji Polski, http://nowadebata. pl/2014/01/18/dwaj-panowie-s-o-pozytkach-z-kolonizacji-polski/

Gardner M., Pseudonauka i pseudouczeni, Warszawa 1966

Grzybowski K., 'Corona regni' a 'Corona Regni Poloniae’, «CPH» 9.2/1957, s. 299-331.

Grzybowski K., Teoria reprezentacji w Polsce epoki odrodzenia, Warszawa 1959 
Historia Polski PAN, I: do roku 1764, 2: do połowy XV w., red. H. ŁowMIAŃsKi, Warszawa 1958

How to Recognize Plagiarism, https://www.indiana.edu/ istd/patterns.html

Kantorowicz E. H., Dwa ciała króla. Studium ze średniowiecznej teologii politycznej, Warszawa 2007

Klimrath H., Histoire du droit. Etudes sur les coutumes, „Revue des Revues de droit publiées à l'étranger", Bruxelles 1839

Lewandowska-Malec I., Artykuł recenzyjny książki Jana Sowy Fantomowe ciało króla. Peryferyjne zmagania z nowoczesna formą, "Krakowskie Studia z Historii Państwa i Prawa» 6(3)/2013, s. 285-301

ŁACHECKi Ł., Rzeczypospolita lacanowska (wrzesień 2012), http://literatki. com/7512/jan-sowa-fantomowe-cialo-krola-rzeczpospolita-lacanowska

MARKiewicz M., Demokracja szlachecka, oligarchia magnacka - zdziejów pewnych pojęć, [w:] Między barokiem a oświeceniem. Apogeum sarmatyzmu. Kultura polska drugiej połowy XVII wieku: praca zbiorowa, red. K. Stasiewicz, S. Achremczyk, Olsztyn 1997

Matuszewski J., Kudrycyzacja, czyli poniewieranie nauki przez biurokracje, «SDPiPP» 18/2015

Mączá A., Klientela. Nieformalne systemy władzy w Polsce i Europie XVI-XVIII w. , wyd. 2, Warszawa 2000

Nowak L., Metodologiczne kryterium demarkacji i problem statusu teologii, «Nauka» 3/2004, s. 121-136.

Olson D.R., Pojęciowe i poznawcze implikacje pisania i czytania, Warszawa 2010

Perspektywy badań nad kulturą, red. R. KLuszczyński, A. Zeidler-JANiSZEWSKA, Łódź 2008

PŁAza S., Wielkie bezkrólewia, Dzieje narodu i państwa polskiego, t. I-22, Kraków 1988

RoJT E., Zygmunt Bauman przepisuje $z$ Wikipedii, albo wielka nauka $i$ małe machlojki, http://kompromitacje.blogspot.com/2014/04/bauman-przepisuje-z-wikipedii.html, lub https://pl.wikipedia.org/wiki/ Zygmunt_Bauman\#cite_note-20

Roudinesco E., Jacques Lacan. Jego życie i myśl, Warszawa 2005

RusıŃski W., Zarys historii gospodarczej Polski na tle dziejów gospodarczych powszechnych, Warszawa 1986

Sienkiewicz B., Państwo na niby, «Przegląd Polityczny» nr 115/116

Silverman S.F., Patronage and Community-Nation Relationships in Central Italy. «Ethnology», 4 (2)/1965, s. 172-189 
SokAl A., BRICMONT J., Modne bzdury: o nadużywaniu pojęć z zakresu nauk ścistych przez postmodernistycznych intelektualistów, Warszawa 2004

Sosnowska A., Zrozumieć zacofanie: spory historyków o Europę Wschodniq (1947-1994), Warszawa 2004

Sowa J., Kiedy dwa minusy nie powinny dawać plusa, Praktyka teoretyczna, http://www.praktykateoretyczna.pl/ jan-sowa-kiedy-dwa-minusy-nie-powinny-dawac-plusal.

Sowa J., Nota na temat artykułu J. Matuszewskiego, «SDPiPP», 18/2015

SowA J., Z takim sposobem uprawiania "polemik naukowych" godzić się nie można. Odpowiedź Wacławowi Uruszczakowi, «SDPiPP», 18/2015

STANisŁaWski A. T., Niedojrzałość, bóle fantomowe i pustka, która nazwano „złotym wiekiem”, «Ruch Literacki» 54.3 (318)/2013,

Teksty źródłowe do nauki historii w szkole. Nr 18 Polska wieś folwarczno-pańszczyźniana w XVI-XVIII wieku, opr. J. BARTYś i J. GolDBERG, Warszawa 1960

Topolski J., Narodziny kapitalizmu w Europie XVI-XVII wieku, Poznań 2003

UruszczaK W., 'In Polonia lex est rex'. Niektóre cechy ustroju Rzeczypospolitej XVI-XVII w., [w:] Polska na tle Europy XVI-XVII wieku, Konferencja Muzeum Historii Polski, Warszawa 2007, Materiały pokonferencyjne, z. 1

URUSZCZAK W., Z takim sposobem uprawiania nauki godzić się nie można. Naruszanie cudzego autorstwa w pracach historycznoprawnych $i$ historycznych, «SDPiPP» 18/2015

Wiśniewski T., Czyja historia, jaka teoria?, http://www.stanrzeczy.edu.pl/ wisniewski-czyja-historia-jaka-teoria/, dostęp 22 listopada 2012 r.

WycZański A., Polska w Europie XVI stulecia, Warszawa 1973

ZajAs K., Fantazmaty Sarmaty albo historia Polskiej Kompanii Kresowej. O dzielnej książce Jana Sowy „Fantomowe ciało króla”, Teksty Drugie, «IBL PAN» 3/2012

Zarycki T., Recenzja książki Jana Sowy, Fantomowe ciało króla. Peryferyjne zmagania z nowoczesna forma. Kraków: Universitas, http://www.iss.uw.edu. $\mathrm{pl} /$ zarycki/pdf/RecenzjaSowa.pdf.

Jacek Matuszewski, Wacław Uruszczak

* 'Uniwersytet Łódzki, Uniwersytet Jagielloński 